\title{
₹USGS
}

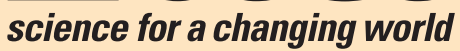

Studies by the U.S. Geological Survey in Alaska, 2010

\section{Streamflow and Streambed Scour in 2010 at Bridge 339, Copper River, Alaska}

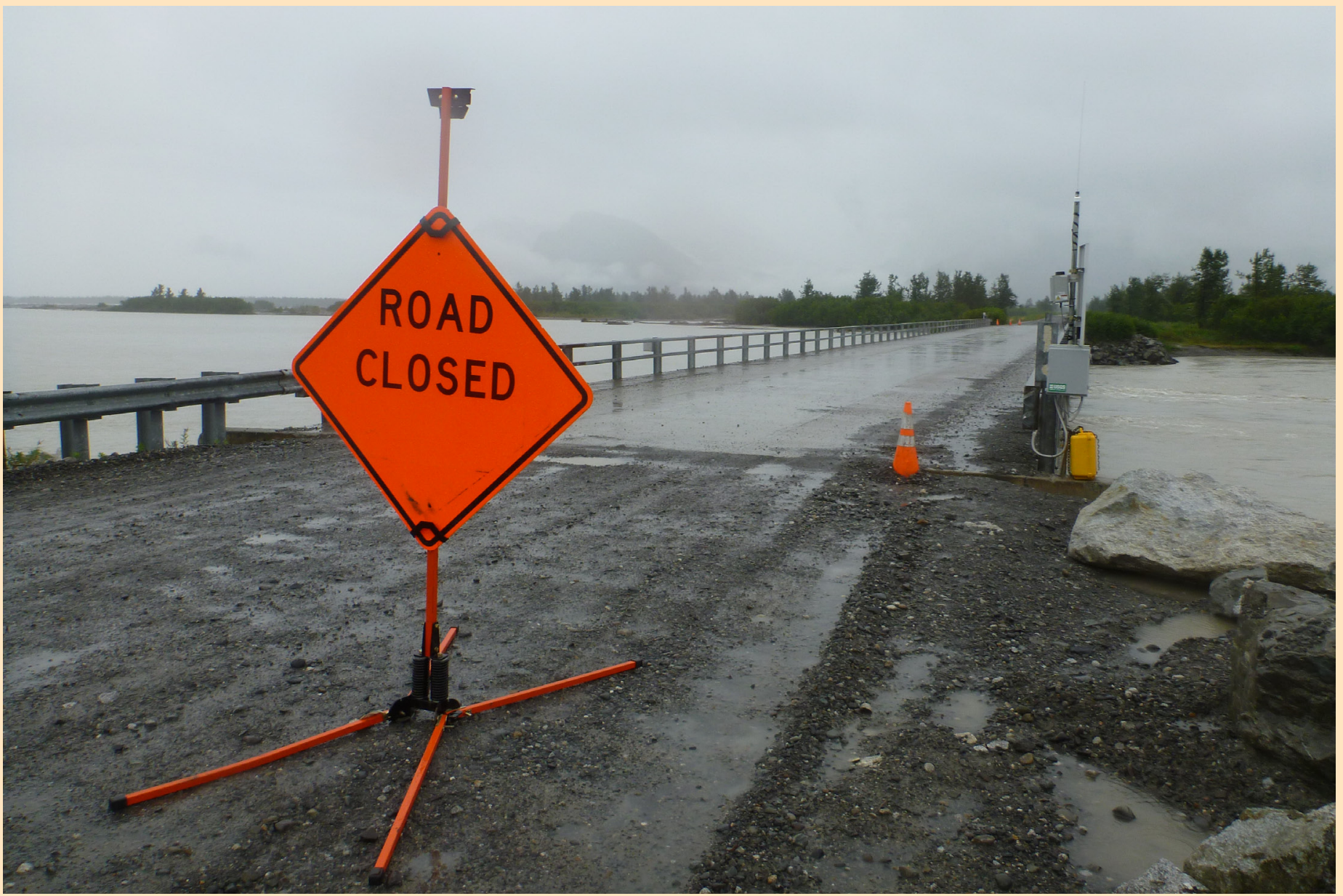

Professional Paper 1784-C

U.S. Department of the Interior

U.S. Geological Survey 
Cover

Photograph of Copper River, Alaska, bridge number (BN) 339. Photograph was taken on August 19, 2011, when streambed scour at the piers and abutments necessitated an indefinite bridge closure.

(USGS photograph by J.S. Conaway.) 
Studies by the U.S. Geological Survey in Alaska, 2010

\section{Streamflow and Streambed Scour in 2010 at Bridge 339, Copper River, Alaska}

By Jeffrey S. Conaway and Timothy P. Brabets

Professional Paper 1784-C

U.S. Department of the Interior

U.S. Geological Survey 


\section{U.S. Department of the Interior KEN SALAZAR, Secretary}

\section{U.S. Geological Survey Marcia K. McNutt, Director}

\section{U.S. Geological Survey, Reston, Virginia: 2011}

This report and any updates to it are available online at:

http://pubs.usgs.gov/pp/1784/c

For more information on the USGS - the Federal source for science about the Earth, its natural and living resources, natural hazards, and the environment:

World Wide Web: http://www.usgs.gov/

Telephone: 1-888-ASK-USGS

Any use of trade, product, or firm names in this publication is for descriptive purposes only and does not imply endorsement by the U.S. Government.

Although this report is in the public domain, it may contain copyrighted materials that are noted in the text. Permission to reproduce those items must be secured from the individual copyright owners.

Library of Congress Cataloging-in-Publication Data

Suggested citation:

Conaway, J.S., and Brabets, T.P., 2011, Streamflow and streambed scour in 2010 at bridge 339, Copper River, Alaska, in Dumoulin, J.A., and Dusel-Bacon, C., eds., Studies by the U.S. Geological Survey in Alaska, 2010: U.S. Geological Survey Professional Paper 1784-C, 24 p. 


\section{Contents}

Abstract

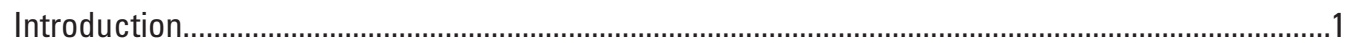

Channel Migration on the Copper River Delta ……..............................................................

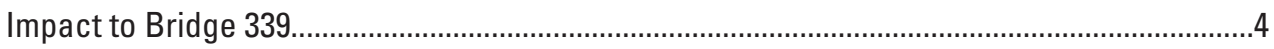

Characteristics and Trends in Flow Distribution.....................................................................

Recent Measurements of Streamflow and Potential Trends ................................................9

Streambed Scour at Bridge Number 339 ........................................................................

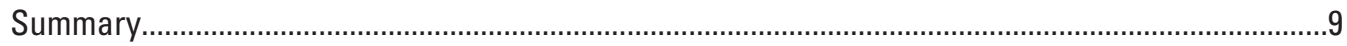

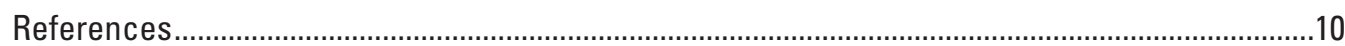

\section{Figures}

1. Map showing the location of the lower Copper River Delta, Alaska.................................2

2. Aerial photograph showing location of bridges across the lower Copper River Delta, Alaska .............................................................................................................

3. Aerial photograph of the lower Copper River, Alaska, near bridge numbers

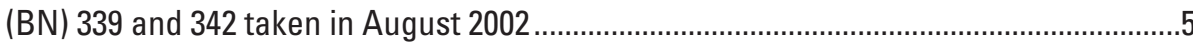

4. Aerial photograph of the lower Copper River, Alaska, near bridge numbers

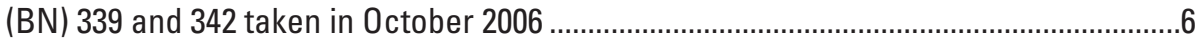

5. Aerial photograph of the lower Copper River, Alaska, near bridge numbers (BN) 339 and 342 taken in August 2007 ....................................................................

6. Aerial photograph showing approach channels to Copper River, Alaska,

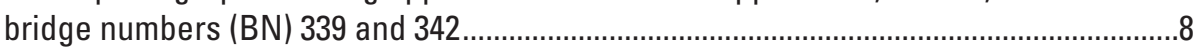

7. Surveyed cross sections along the downstream side of Copper River, Alaska,

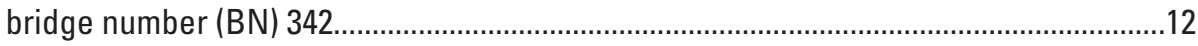

8. Water-surface elevations from the November 7, 2009, lidar dataset.............................13

9. Discharge measurements from 2005-2010 at Copper River, Alaska, bridge number (BN) 339 .....................................................................................

10. Discharge measurements from 2005-2010 at Copper River, Alaska, bridge

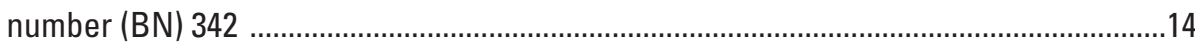

11. Pier soundings, stage, and sonar values from 2010 at Copper River, Alaska,

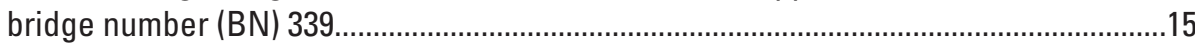

12. Discharge measurements from 2005-10 at Copper River, Alaska, bridge numbers (BN) 331, 1187, and 332

13. Aerial photograph of approach channels to Copper River, Alaska, bridge numbers (BN) 339 and 340

14. Photographs showing undermining and erosion of rip rap over a 24-hour period ........17

15. Surveyed cross sections along the downstream side of Copper River, Alaska, bridge number (BN) 339

16. Velocity contour plots from discharge measurements made during 2010 at Copper River, Alaska, bridge number (BN) 339.

\section{Tables}

1. Discharge measurements made in 2010 at Copper River, Alaska.................................24

2. Summary of discharge measurements made in $\mathbf{2 0 1 0}$ at Copper River, Alaska...............24

3. Pile-tip elevations, minimum embedment depths ( 35 foot minimum), and minimum measured bed elevations at Copper River, Alaska. 
This page intentionally left blank 


\title{
Summary of Streamflow and Streambed Scour in 2010 at Bridge 339, Copper River, Alaska
}

\author{
By Jeffrey S. Conaway and Timothy P. Brabets
}

\section{Abstract}

The Copper River Highway traverses a dynamic and complex network of braided and readily erodible channels that constitute the Copper River Delta, Alaska, by way of 11 bridges. Over the past decade, several of these bridges and the highway have sustained serious damage from both high and low flows and channel instability. This investigation studying the impact of channel migration on the highway incorporates data from scour monitoring, lidar surveys, bathymetry, hydrology, and time-lapse photography.

The distribution of the Copper River's discharge through the bridges was relatively stable until sometime between 1969-70 and 1982-85. The majority of the total Copper River discharge in 1969-70 passed through three bridges on the western side of the delta, but by 1982-1985, 25 to 62 percent of the flow passed through bridge 342 on the eastern side of the Copper River Delta. In 2004, only 8 percent of the flow passed through the western bridges, while 90 percent of the discharge flowed through two bridges on the eastern side of the delta. Migration of the river across the delta and redistribution of discharge has resulted in streambed scour at some bridges, overtopping of the road during high flows, prolonged highway closures, and formation of new channels through forests. Scour monitoring at the eastern bridges has recorded as much as 44 feet of fill at one pier and 33 feet of scour at another. In 2009, flow distribution began to shift from the larger bridge 342 to bridge 339. In 2010, flow in excess of four times the design discharge scoured the streambed at bridge 339 to a level such that constant on-site monitoring was required to evaluate the potential need for bridge closure. In 2010, instantaneous flow through bridge 339 was never less than 30 percent and was as high as 49 percent of the total Copper River discharge. The percentage of flow through bridge 339 decreased when the overall Copper River discharge increased. The increased discharge through bridge 339 is attributed to a shift in the approach channel 3,500 feet upstream. Bridge channel alignment and analysis of flow distribution as of October 2010 indicate these hydrologic hazards will persist in 2011.

\section{Introduction}

The Copper River basin encompasses $24,000 \mathrm{mi}^{2}$ of mountainous terrain that includes the Alaska Range to the north, the Wrangell-St. Elias Mountains to the east, the Talkeetna Mountains to the west, and the Chugach Mountains near the river's mouth. It is the sixth largest river basin in Alaska, but the average discharge of the Copper River, $57,400 \mathrm{ft}^{3} / \mathrm{s}$, ranks second behind that of the Yukon River. The Copper River is the only river that cuts through the Chugach Mountains and was a historical corridor for travel between coastal and interior Alaska in the 1800s and early 1900s. The study area of the lower Copper River consists of the area bounded by Miles Lake to the north and the Copper River Highway to the south (fig. 1). Downstream of Miles Lake outlet, the river flows past the face of Childs Glacier and then branches out into a complex network of braided channels for $30 \mathrm{mi}$ before emptying into the Gulf of Alaska. The channel and banks are composed of readily erodible material and the river is constantly scouring and migrating across its braid plain. Brabets (1997) determined that the lower Copper River transports 69 million tons of suspended sediment per year. The composition of bedload material being transported by the lower Copper River can be classified as coarse sand to medium gravel.

The Copper River Highway traverses this dynamic and complex alluvial plain by way of 11 bridges (fig. 2). The Highway follows the historic route of the Copper River and Northwestern Railway that connected the town of Cordova with the Kennecott copper mines in 1911. The railway was converted to vehicular traffic in 1945, but only as far as the historic Million Dollar Bridge. Changes in flow distribution across the lower Copper River braid plain have notably stressed two bridges, bridge number (BN) 339 and BN 342, which have been subject to streambed scour resulting from an overall eastward migration of the Copper River.

\section{Channel Migration on the Copper River Delta}

Braided rivers are characterized by wide channels, constant movement of bed material, and continuous shifting 


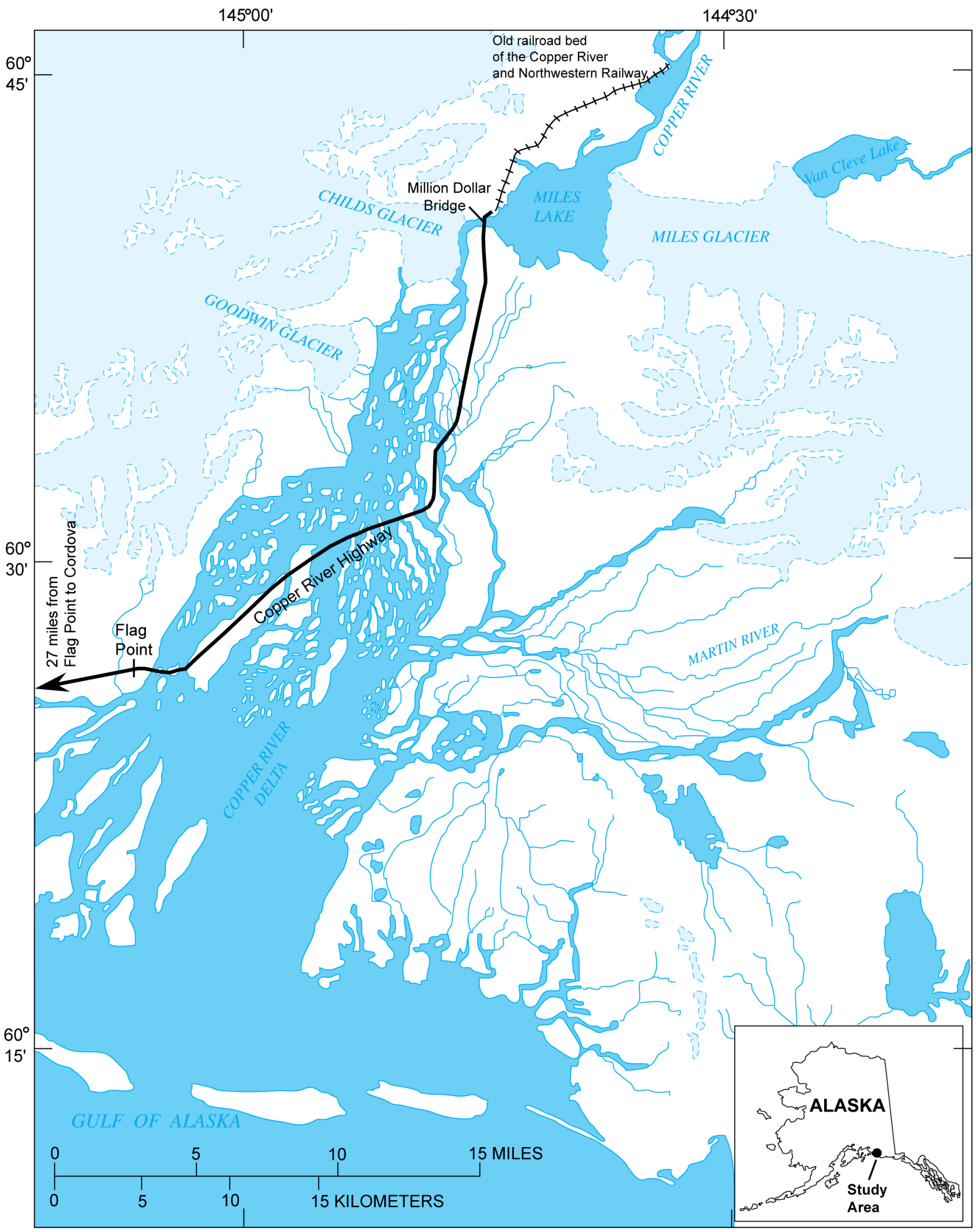

Figure 1. Map showing the location of the lower Copper River Delta, Alaska. 


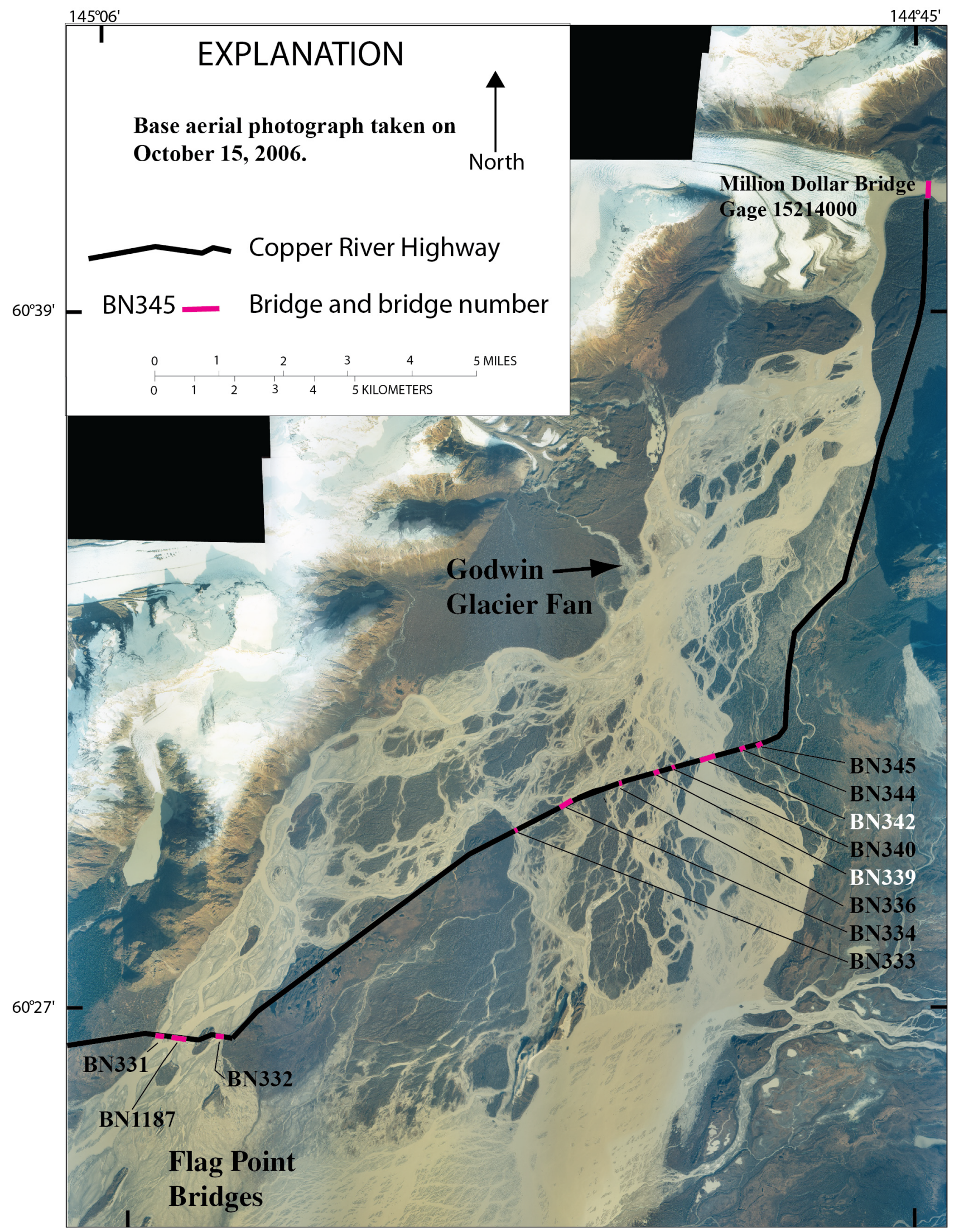

Figure 2. Aerial photograph showing location of bridges across the lower Copper River Delta, Alaska. (USGS image.) 
of channel position (Leopold and others, 1964). Although braided rivers constantly adjust to changes in discharge and sediment load at low to normal flows, major changes usually occur during high flows (Hickin and Sichingabula, 1988). Discharge of the lower Copper River ranges from $5,000 \mathrm{ft}^{3} / \mathrm{s}$ during winter low flows to more than $400,000 \mathrm{ft}^{3} / \mathrm{s}$ during glacial outburst and storm-induced floods. Cold-region rivers experience additional morphological pressures, particularly during the spring break up of ice. For example, a temporary ice jam that formed on the Copper River in 2006 diverted a part of the river eastward, forming new channels and washing out the highway (Brabets and Conaway, 2009).

When the Copper River and Northwestern Railway crossed the braid plain, the majority of flow was along the western edge of the Copper River Delta. Flow distribution remained relatively stable until sometime in the 1970s to early 1980s. An analysis of discharge data by Brabets (1997) determined that most of the flow that passed the Million Dollar Bridge in 1969-70 passed through three bridges at Flag Point (BN 331, 332, and 1187) (fig. 2). Analysis of the next available dataset from 1982-85 indicated a shift in flow distribution from these bridges to BN 339 and BN 342 . During this period, flow at BN 342 ranged from 25 to 64 percent of the total Copper River discharge (Brabets, 1997). At discharges less than $100,000 \mathrm{ft}^{3} / \mathrm{s}$, more than 50 percent of the flow passed through BN 342 between 1982 and 1985 (Brabets, 1997). Brabets (1997) concluded the main channel of the Copper River shifted toward this bridge sometime between 1970 and 1982. This shift was attributed to a flood in 1981 that had a 1-percent annual exceedance probability (AEP) (Brabets, 1997). This flood also initiated bank erosion on the east side of the upper braid plain (Brabets, 1997).

\section{Impact to Bridge 339}

From June to August, 2010, streamflow at BN 339 continually exceeded $45,000 \mathrm{ft}^{3} / \mathrm{s}$, nearly three times the design discharge of $17,500 \mathrm{ft}^{3} / \mathrm{s}$. The excessive discharge began to affect BN 339 in 2001 and the bridge was added to the Alaska Department of Transportation and Public Facilities scour-critical list. Sonars for measuring streambed depths were installed initially at the left and right bank piers. As scour conditions worsened in 2010, all four piers were instrumented. The percentage of total Copper River flow (as measured at gaging station number 15214000) passing through BN 339 has increased dramatically since 2009. By June 2010, flow alignment to the bridge opening caused severe erosion around the right-bank abutment that required emergency placement of rip rap to protect the western approach to the bridge. The streambed scoured to a level at which minimum pile embedment criterion for lateral stability was barely satisfied for piers 2 and 3. In mid-June, turbulence created by flow velocities in excess of $15 \mathrm{ft} / \mathrm{s}$ prevented accurate sonar readings at pier 2. For the next six weeks, bed elevations, as measured with a 300-pound sounding weight, remained at 1 to 4 feet above the threshold for bridge closure. State engineers were forced to decide between continuing costly on-site monitoring, bridge closure, or keeping the bridge open with less frequent monitoring. The decision was made to continue the daily monitoring only if the watersurface elevation at the bridge increased beyond previously observed levels. Biweekly channel soundings collected over the remainder of the summer indicated bed elevations did not drop below threshold values for bridge closure. Channel alignment and analysis of flow distribution as of October 2010 indicate that hydrologic hazards will persist in 2011 at BN 339.

\section{Characteristics and Trends in Flow Distribution}

There have been three distinct changes in distribution of flow on the Copper River Delta that notably affect BN 339 . The first was the large-scale eastward shift of flow from the Flag Point bridges toward BN 339 and BN 342 that occurred sometime between 1969-70 and 1982. From 1950 to 1995, flow that passed through BN 339 ranged from less than 1 to 5 percent of the total flow- $1,000 \mathrm{ft}^{3} / \mathrm{s}$ to $14,600 \mathrm{ft}^{3} / \mathrm{s}$-well below the design discharge for the bridge (Brabets, 1997). The second shift in flow occurred sometime between 1995 and 2005. Analysis of discharge measurements indicated that at average flow conditions, flow at the Flag Point bridges shifted from approximately 50 percent of the total during 1991-95 to approximately 5 percent of the total during 2005-7, and flow passing through BN 339 and BN 342 increased from 50 percent of the total during 1991-1995 to 95 percent of the total during 2005-7 (Brabets and Conaway, 2009). Measurements from 2005-10 indicate that the flow toward the Flag Point bridges increases proportionately with increases to the overall discharge of the Copper River.

The last shift in flow distribution was more localized between BN 339 and BN 342. Beginning in July 2009, the flow distribution between BN 339 and BN 342 started shifting toward BN 339. This stepwise shift was most likely initiated by deposits made during flooding in October 2006 when the total flow on the Copper River reached $444,000 \mathrm{ft}^{3} / \mathrm{s}$ but did not manifest in a change in distribution until 2009. Figures 3 through 6 show the growth of a depositional bar with an approximate east-west orientation that is located 4,500 $\mathrm{ft}$ upstream of BN 342. This bar diverts flow to the west, keeping low flows from directly approaching BN 342. After a flood in October 2006, flow distribution through BN 342 remained relatively constant, but most of the flow through the bridge shifted from the right section of the bridge to the left (fig. 7; note that figs. 7-16 are found at the back of this report). The bar deposits created a sinusoidal approach to BN 342 that eventually split in 2009 with channels leading to both $\mathrm{BN} 339$ and $\mathrm{BN} 342$. BN 339 then received a greater percentage of the overall discharge at lower flows, but at higher flows approach channels to BN 342 are activated and the percentage of flow exceeds that at BN 339 (table 1; note that tables 1-3 are found at the back of this report). The total Copper River discharge was similar for concurrent 


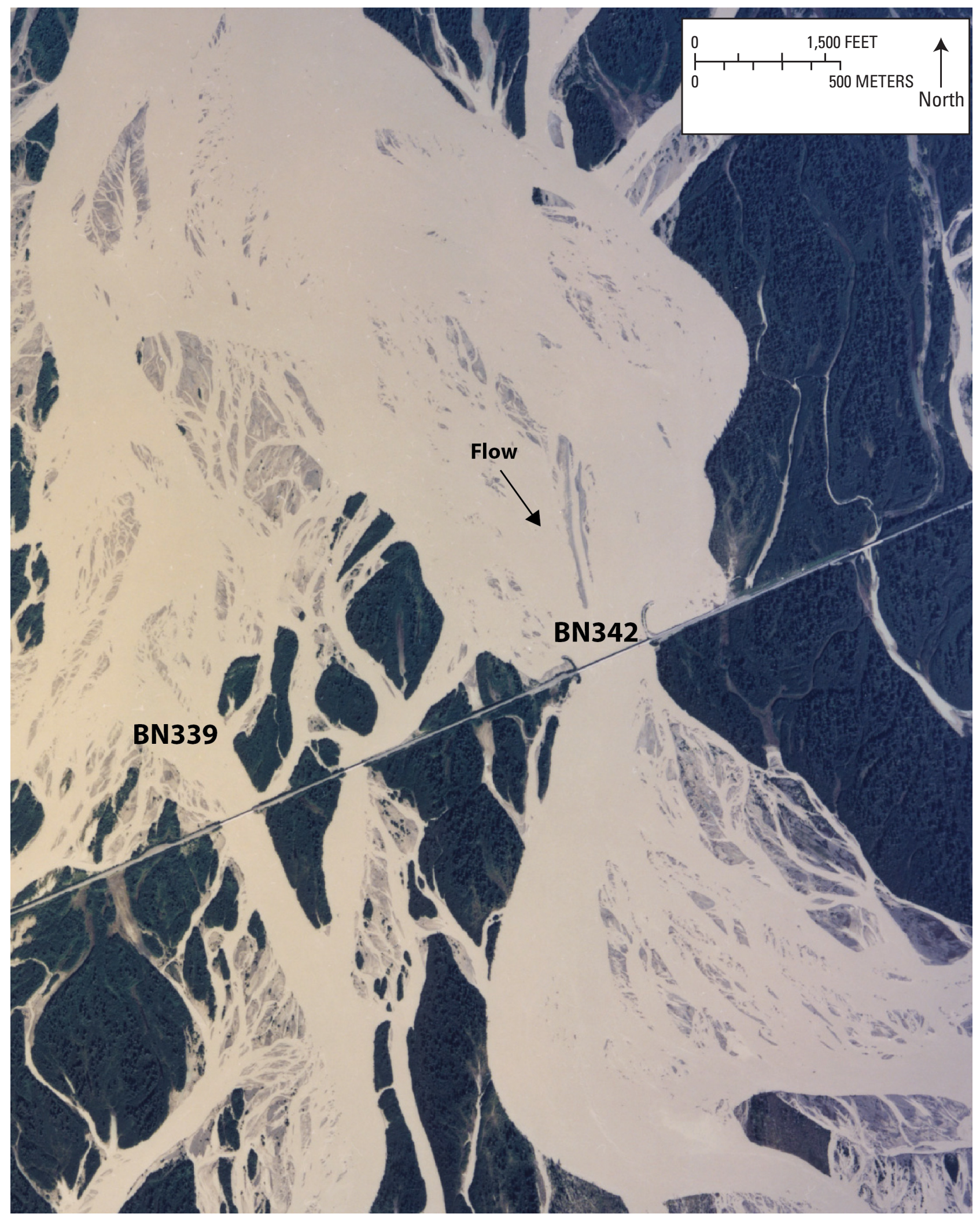

Figure 3. Aerial photograph of the lower Copper River, Alaska, near bridge numbers (BN) 339 and 342 taken in August 2002. (USGS image.) 


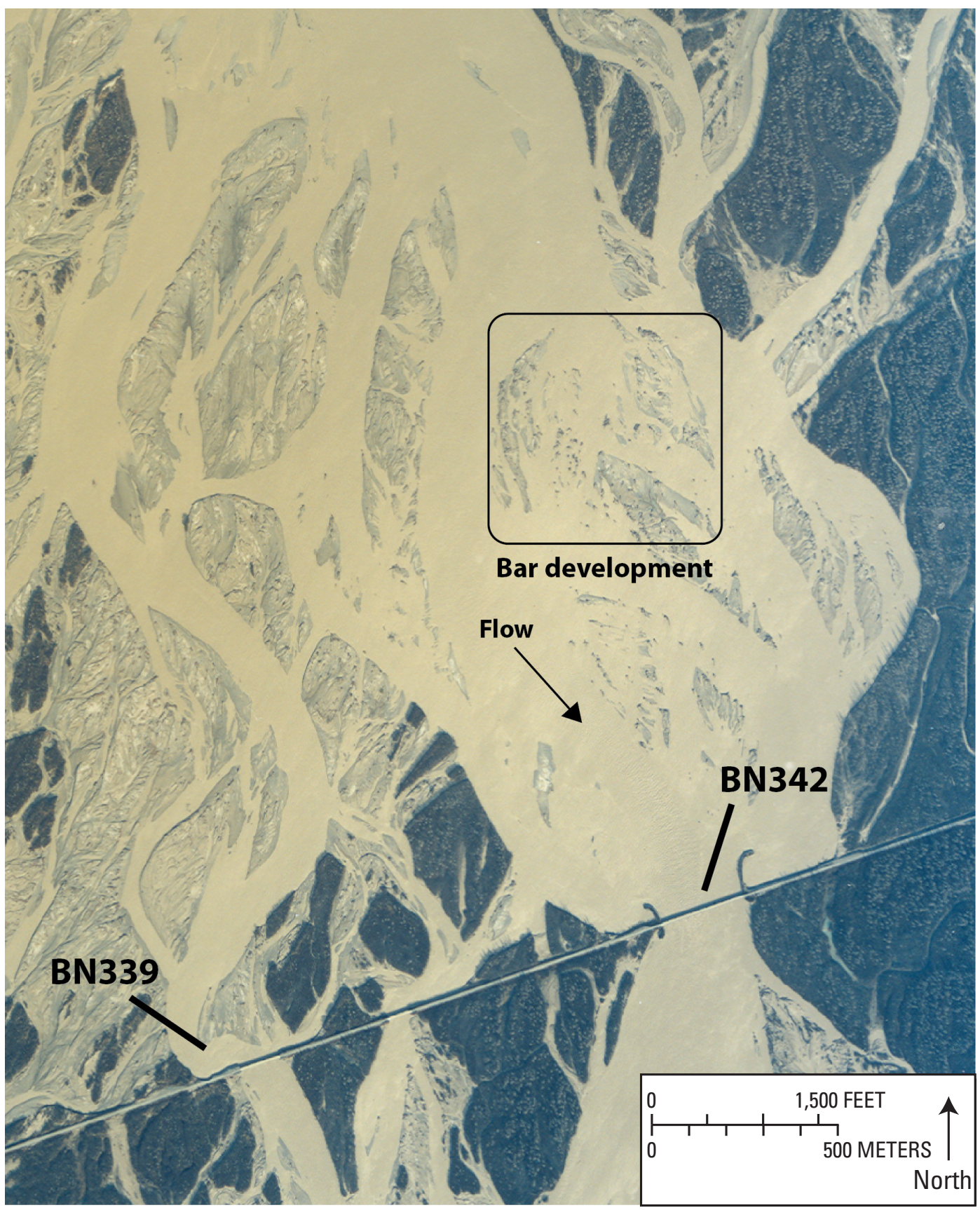

Figure 4. Aerial photograph of the lower Copper River, Alaska, near bridge numbers (BN) 339 and 342 taken in October 2006. Area within the box is the location of mid-channel bar development after 0ctober 2006 flooding. (USGS image.) 


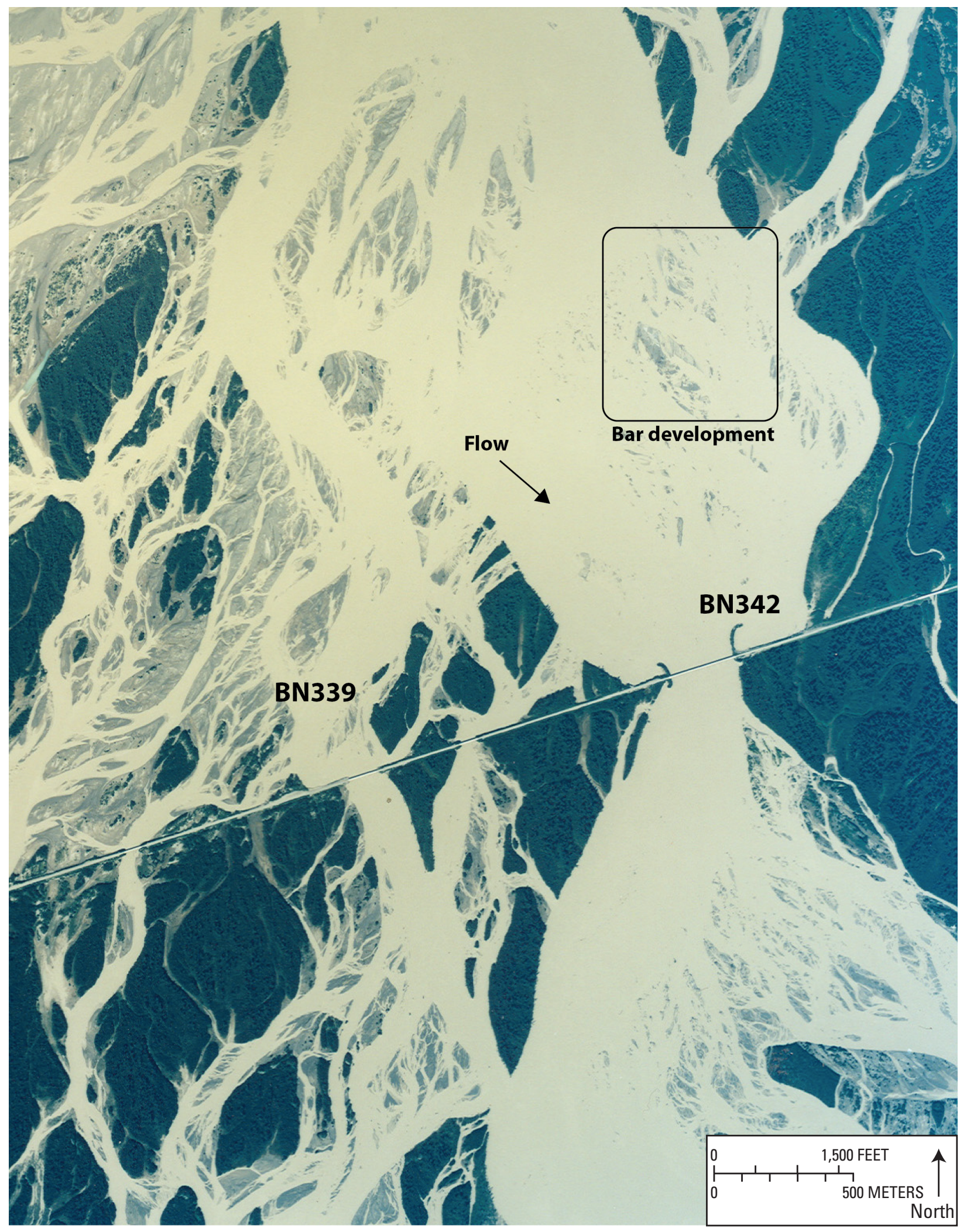

Figure 5. Aerial photograph of the lower Copper River, Alaska, near bridge numbers (BN) 339 and 342 taken in August 2007. Area within the box is the location of mid-channel bar development initiated by deposits from 0ctober 2006 flooding. (USGS image.) 
measurements made on June 9-10 and August 31-September 1, 2010. The percentage of flow passing through BN 339 relative to $\mathrm{BN} 342$ was greater during the second measurement. On June 9-10, the percentage of flow passing through BN 339 and BN 342 was 39 and 46 percent, respectively. On August 31-September 1, 2010, the percentage of flow passing through BN 339 and BN 342 was 42 and 37 percent, respectively. This indicates that the low-flow channels to $\mathrm{BN}$ 339 are becoming more established and that the trend toward increased flow passing BN 339 may continue. Field observations in September 2010 upstream of the 2 bridges indicate that the channel to $\mathrm{BN} 339$ was larger and more established than the channel to BN 342.

The most recent lidar data on the Copper River was collected on November 7, 2009. Discharge on the Copper River at this time was $16,800 \mathrm{ft}^{3} / \mathrm{s}$. At this discharge, only the deepest channels on the braid plain actively convey water. A sinuous, single-thread channel approaches BN 339 and BN 342 and then bifurcates approximately 3,500 ft upstream of BN 339. There are three distinct water-surface slopes along this channel (fig. 8). The upstream section slope is the greatest at $0.0013 \mathrm{ft} / \mathrm{ft}$ and this part of the channel traverses from east to west across the braid plain. The slope of the next section is nearly flat at $0.00004 \mathrm{ft} / \mathrm{ft}$ for $3,600 \mathrm{ft}$ until the slope increases to $0.0008 \mathrm{ft} / \mathrm{ft}$ through $\mathrm{BN}$ 339. Reductions in slope along a river result in decreased sediment transport capacity, deposition of sediment as bars, and diversion of flow toward the outer banks (Leopold and others, 1964). The bifurcation is located near the apex of large curve in the low-flow channel. Migration of this lowflow channel will likely continue west and continue to favor flow toward BN 339.

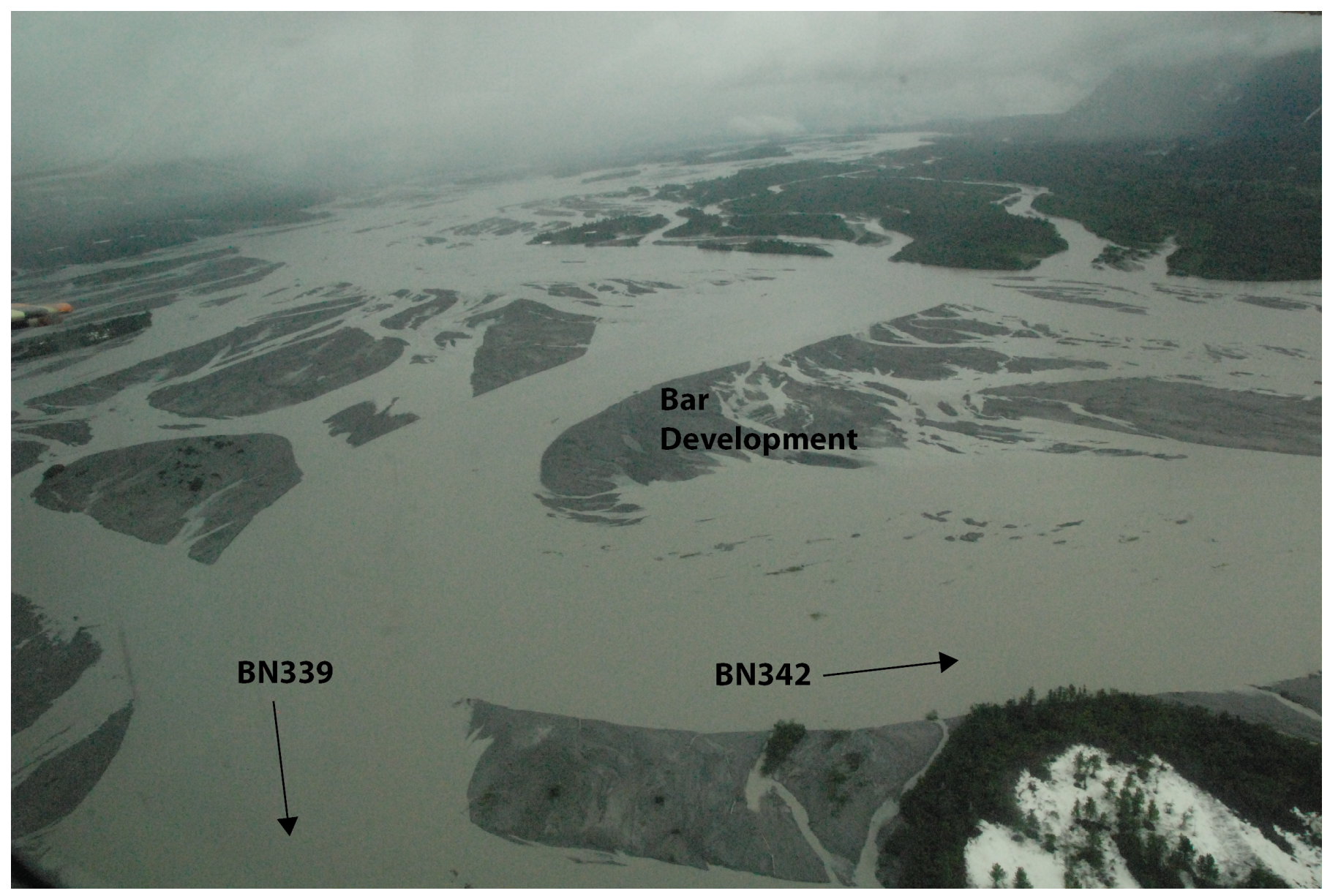

Figure 6. Aerial photograph showing approach channels to Copper River, Alaska, bridge numbers (BN) 339 and 342 . Photograph was taken on July 1, 2010, at a discharge of 60,300 ft³ $/ \mathrm{s}$ at BN 339 and a total river discharge of 160,000 ft $3 / \mathrm{s}$. Area labeled Bar Development is the location of mid-channel bar development that was initiated by flood deposits in October 2006. (USGS photograph by J.S. Conaway.) 


\section{Recent Measurements of Streamflow and Potential Trends}

Discharge measurements in 2009 indicated a shift in flow distribution from BN 342 to BN 339. In 2010, as much as 49 percent of the total flow of the Copper River went through BN 339 (fig. 9). However, the discharge at BN 339 remained relatively constant through the open-water season compared with the overall discharge of the Copper River, and the percentage of flow through BN 339 decreased when the overall Copper River discharge increased (fig. 9, table 2). In 2010, flow through BN 339 was never less than 30 percent of the total Copper River discharge. Over the same time period, a decreased percentage of the total Copper River flow passed through BN 342 to the east (fig. 10). The measured discharge at BN 342 from 2005 through September of 2009 was only once less than 50 percent of the total Copper River flow but never exceeded 45 percent in 2010. The percentage of flow passing through BN 339 was higher for the lower discharges in spring and fall of 2010 (49.2 percent on September 22) indicating that this is an established channel. From June to August 2010 streamflow at BN 339 was in excess of 45,000 $\mathrm{ft}^{3} / \mathrm{s}$, and the maximum stage was recorded on August $5(51.8$ $\mathrm{ft}$ (all elevations in this report are in the datum of the bridge as-built plans) (fig. 11). In 2010, ten discharge measurements were made at BN 339 (table 2), with discharge ranging from $35,700 \mathrm{ft}^{3} / \mathrm{s}$ to $74,000 \mathrm{ft}^{3} / \mathrm{s}$.

As stage increases, water/flow enters the channels to the Flag Point bridges. The measured discharge at the three Flag Point bridges from 2005 through June 2009 was never greater than 25 percent of the total Copper River discharge (fig. 12). The distribution of flow to the Flag Point bridges - BN 331, BN 332, and BN 1187-has remained consistent from 2005 to 2010 (fig. 12).

It is not possible to make accurate long-term predictions about how much flow will pass any given bridge on the Copper River Delta. For example, a large flood most likely would result in significant channel change. For discharges less than 100,000 $\mathrm{ft}^{3} / \mathrm{s}$ at the Million Dollar Bridge, 90 to 100 percent of the discharge will likely be directed toward BN 339 and BN 342. Given the current channel conditions, it is not unreasonable to expect most of this flow to be directed toward BN 339. As the discharge increases beyond $100,000 \mathrm{ft}^{3} / \mathrm{s}$ more channels in the braid plain are activated and the discharge is more evenly distributed between BN 339 and BN 342 and the remainder of the bridges along the highway.

An analysis to determine a possible maximum flow through BN 339 was made using data from the 2009 and 2010 discharge measurements. The greatest measured depth for each location along the bridge cross section was determined from the discharge measurements. These depths do not necessarily represent the maximum possible depth, but represent known available channel area that is not resistant to scour. A channel area of $11,300 \mathrm{ft}^{2}$ was computed for this cross section using the maximum observed stage from 2010 of $51.8 \mathrm{ft}$. The maximum measured velocity was determined for each location, and the average of these values is $8.65 \mathrm{ft} / \mathrm{s}$. Using these values, a discharge of $97,400 \mathrm{ft}^{3} / \mathrm{s}$ was computed.

\section{Streambed Scour at Bridge Number 339}

The main channel to BN 339 has changed continuously from 2002 to 2010. Brabets and Conaway (2009) documented the migration of this channel initially toward the west (right bank) and then back toward the east (left bank) in 2008. In 2010, the approach channel was skewed to the bridge opening and directly attacked the right bridge abutment (figs. 13 and 14). This migration reduced undermining and scour along the right bank approach, but increased these processes at the right bank abutment and scoured the streambed across the channel (figs. 15 and 16). Channel area below a datum of $50.0 \mathrm{ft}$ increased from $4,130 \mathrm{ft}^{2}$ on July 1,2009 , to $8,850 \mathrm{ft}^{2}$ on July 6,2010 . This increase in channel area was the result of as much as $20 \mathrm{ft}$ of scour along the left part of the channel as the approach channel became more aligned with the bridge opening. Maximum channel depths were along the right side of the channel, and scour at piers 2 and 3 nearly reached the criterion for minimum embedment.

Continuous scour monitoring with pier-mounted sonars was successful at piers 3, 4, and 5, but air entrainment and a hydraulic jump on the downstream side of pier 2 prevented accurate data collection (fig. 11). During a site visit on July 14, 2010 , pier 2 was observed to be oscillating a quarter of an inch because $45 \mathrm{ft}$ of the pier was in the water column and measured velocities near the pier exceeded $9 \mathrm{ft} / \mathrm{s}$ at depths as great as $35 \mathrm{ft}$ (fig. 16). Streambed elevation at pier 2 ranged from 5.9 to $9.0 \mathrm{ft}$ for the entire summer and did not infill as stage decreased in September and October. It is possible that rip rap eroded from the right bank abutment armored the streambed preventing further scouring of the channel near pier 2 .

Changes in channel area in 2010 resulted from scour and fill along the left and center parts of the channel. The location of the approach channel relative to the bridge opening determines the shape of the bridge cross section by directing the highest velocities toward one bank or the other. Bed elevations increased at piers 4 and 5 as stage receded in August but decreased at pier 3 . Widening of the main channel toward the center of the channel (scour at pier 3) may indicate a resistance to additional scour at pier 2; however, thalweg migration in this direction threatens the integrity of pier 3 , which has the shallowest pile-tip elevation (table 3 ). The criterion for minimum embedment depth for lateral loading is $35 \mathrm{ft}$. The minimum measured bed elevations in 2010 were near this criterion for piers 2, 3, and 5 (table 3 ). Continued thalweg expansion or migration toward the left bank may scour the streambed beyond minimum embedment elevations at piers 3 and 5 .

\section{Summary}

BN 339 has experienced significant scour at piers, abutments, and approaches as a result of major channel shifts of 
the Copper River initiated during flooding in 1981. A secondary shift in the approach channel from BN 342 to BN 339 was concurrent with deposits that formed after flooding in 2006. Discharge through BN 339 ranged from 34 to 49 percent of the total Copper River discharge during the period of open water in 2010. The highest measured discharge through BN 339 in 2010 was $74,000 \mathrm{ft}^{3} / \mathrm{s}$, more than four times the design discharge for the bridge. The resultant streambed scour doubled channel area at the bridge between 2009 and 2010.

Conditions in 2010 were closely monitored with crosssectional surveys, discharge measurements, scour monitoring equipment, and time-lapse photography. Scour at the rightbank abutment required emergency placement of rip rap in late June 2010. Streambed elevation at the right-bank pier (pier 2) was within in $1 \mathrm{ft}$ of the threshold for minimum embedment depth and was monitored daily with manual soundings for 6 weeks. Bed elevations along the right bank reached a minimum in June of 2010 and fluctuated little through the rest of the summer despite changes in discharge. Increases in channel area resulted from widening of the thalweg toward the center of the channel and pier 3. The streambed was within $2.3 \mathrm{ft}$ of the limit for minimum embedment at pier 3 during the last cross-sectional survey on October 14, 2010.

It is not possible to make accurate long-term predictions about how much flow will pass any given bridge on the Copper River Delta, but using the observed trends and historic flow distribution does provide some boundaries for possible maximum flows. At discharges less than $100,000 \mathrm{ft}^{3} / \mathrm{s}$ at the Million Dollar Bridge, 90 to 100 percent of the discharge has been directed toward $\mathrm{BN} 339$ and $\mathrm{BN}$ 342, with the majority of the discharge directed toward BN 339. As the total Copper River discharge increases beyond $100,000 \mathrm{ft}^{3} / \mathrm{s}$, additional braid-plain channels are activated and discharge is distributed more between BN 339 and BN 342 and the remainder of the bridges along the highway. The behavior of the braided channel is extremely complex, with mid-channel bars upstream and downstream of the Copper River Highway deflecting flow, forming in response to channel migration, and causing backwater that can limit streambed scour in an unpredictable manner. It may not be possible to predict whether the channel might revert to its pre-1980 configuration, continue to increase the proportion of flow through BN 339 and 342, or migrate even further to the east.

\section{References}

Brabets, T.P., 1997, Geomorphology of the Lower Copper River, Alaska: U.S. Geological Survey Professional Paper 1581,89 p.

Brabets, T.P., and Conaway, J.S., 2009, Geomorphology and river dynamics of the lower Copper River, Alaska: U.S. Geological Survey Scientific Investigations Report 2009-5257, 42 p., available at http://pubs.usgs.gov/ sir/2009/5257/.

Hickin, E. J., and Sichingabula, H.M., 1988, The geomorphic impact of the catastrophic October 1984 flood on the planform of the Squamish River, southwestern British Columbia: Canadian Journal of Earth Sciences, v. 25, p. 1078-1087.

Leopold, L.B., Wolman, M.G., and Miller, J.P., 1964, Fluvial processes in geomorphology: San Francisco, Calif., W.H. Freeman and Company, 522 p. 
Figures 7 through 16 


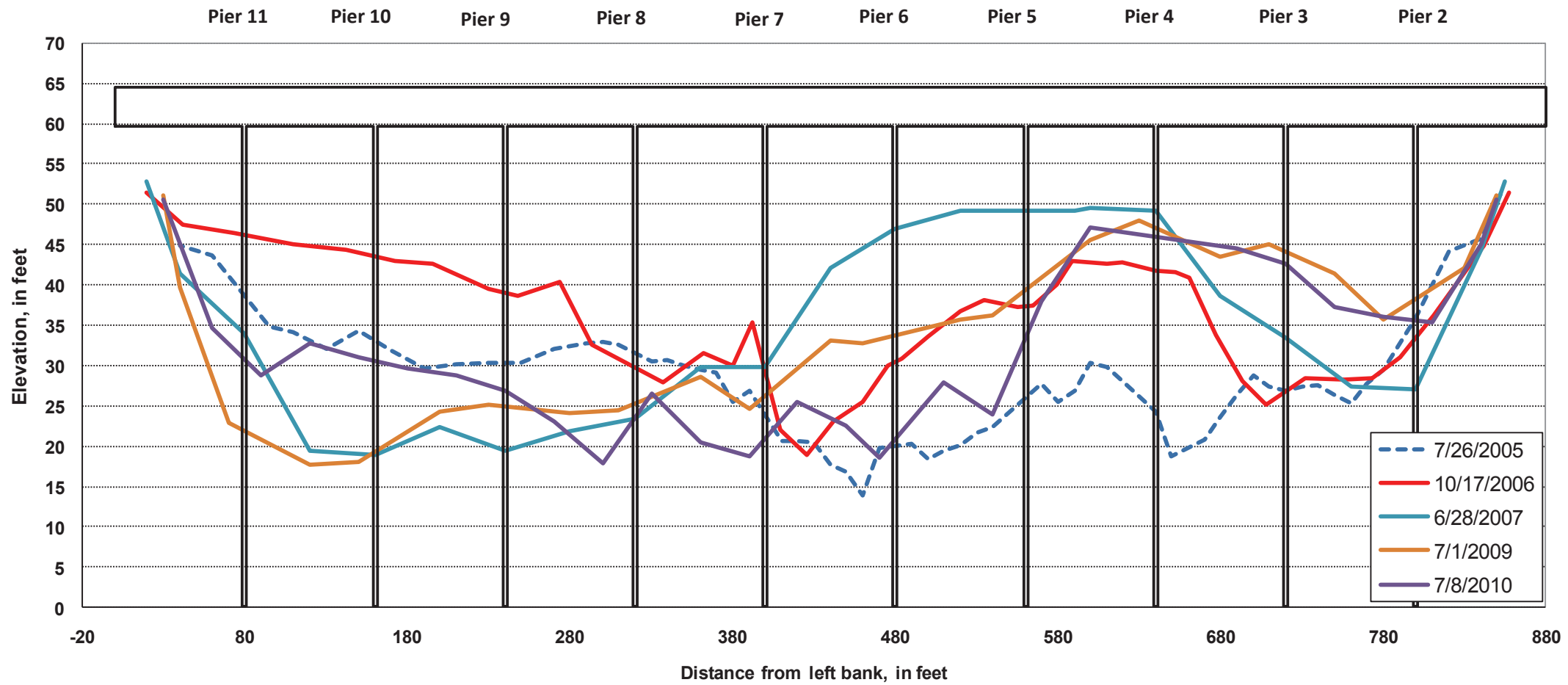

Figure 7. Surveyed cross sections along the downstream side of Copper River, Alaska, bridge number (BN) 342. The dashed cross section was surveyed before a October 2006 flood, and the remainder of the cross sections were surveyed after the flood. 

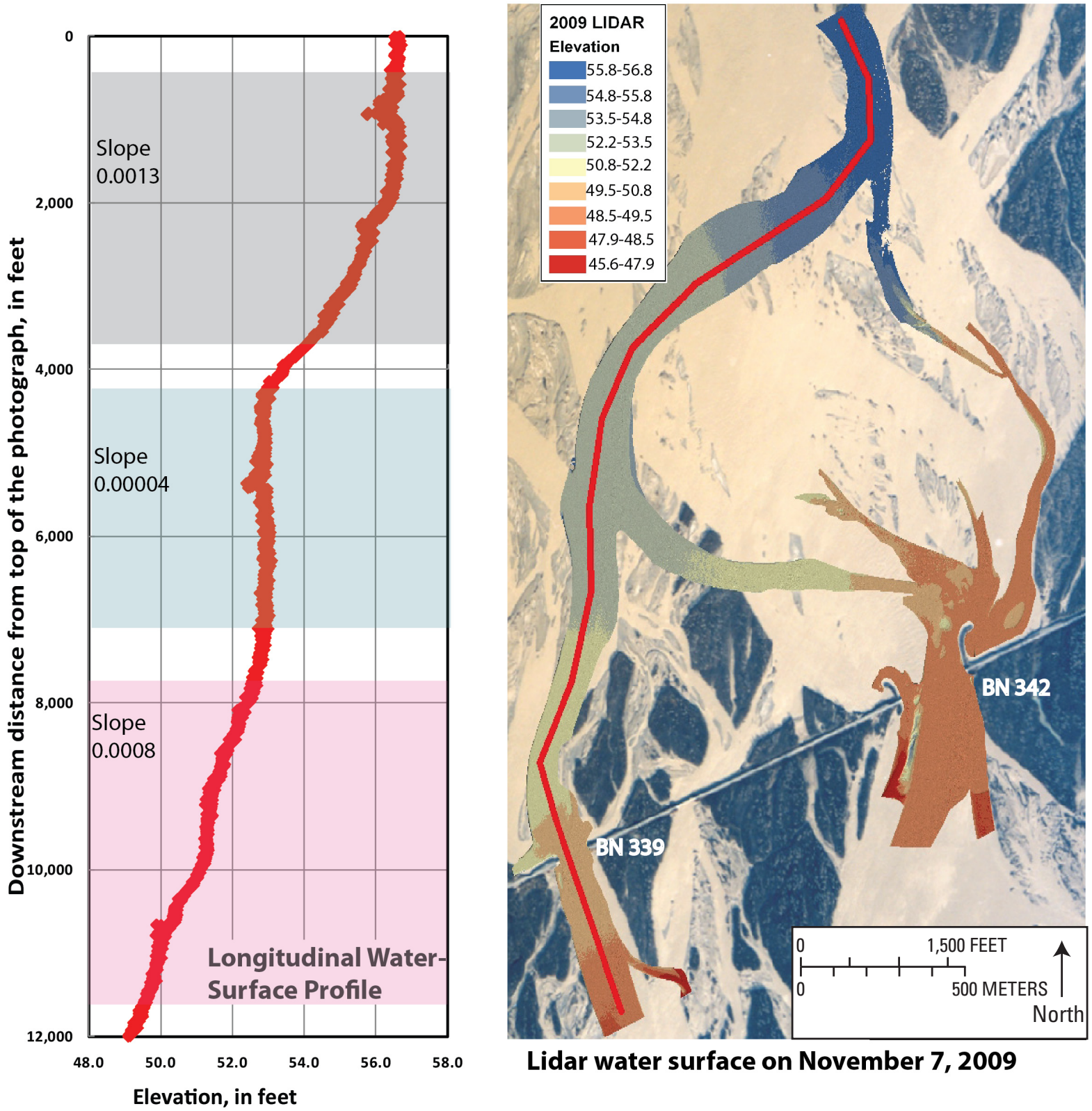

Lidar water surface on November 7, 2009

Figure 8. Copper River, Alaska, water-surface elevations from the November 7, 2009, lidar dataset that was collected at a total discharge of $16,800 \mathrm{ft}^{3} / \mathrm{s}$. (USGS image.) 


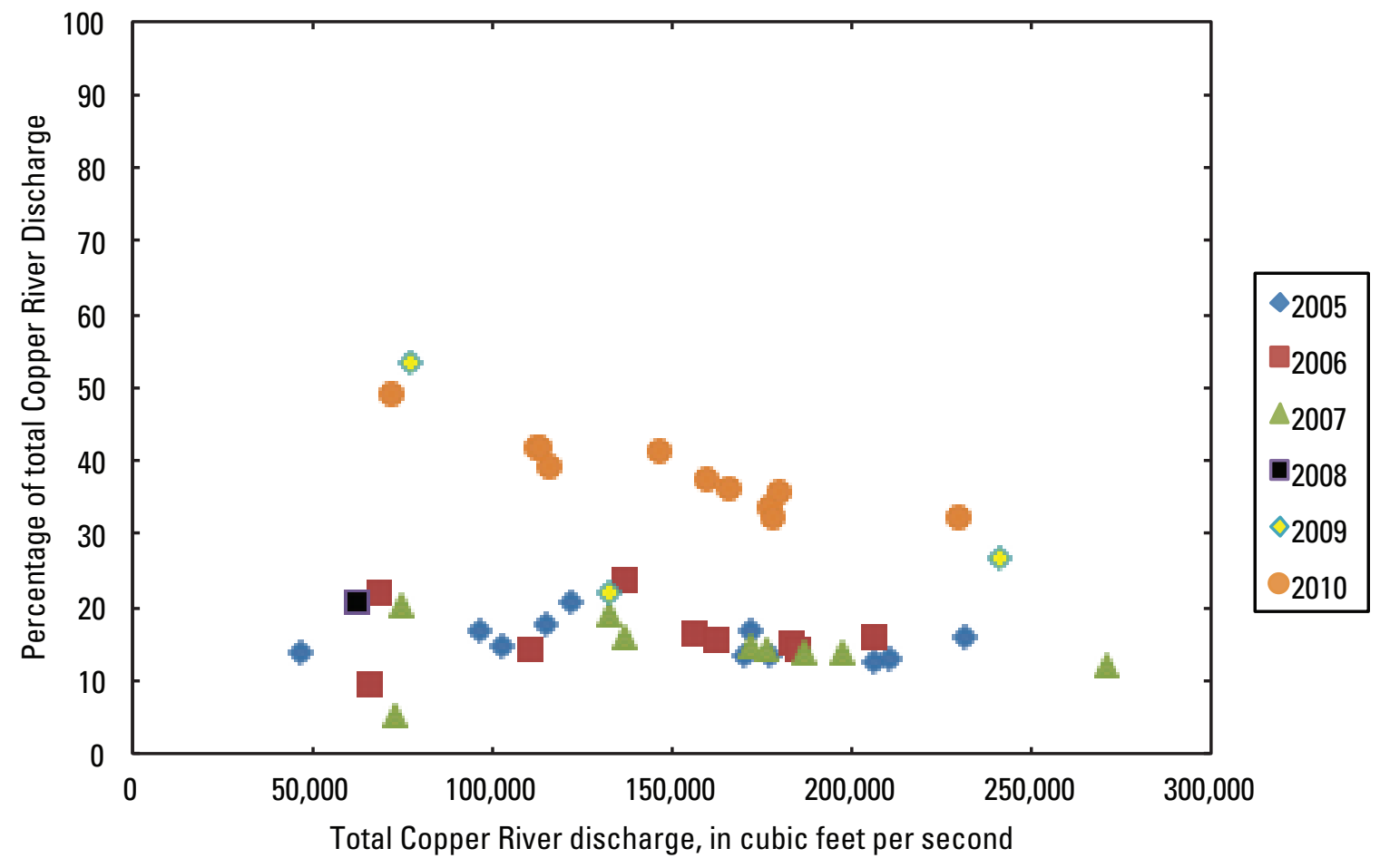

Figure 9. Discharge measurements from 2005-10 at Copper River, Alaska, bridge number (BN) 339 and their percentage of the total river discharge.

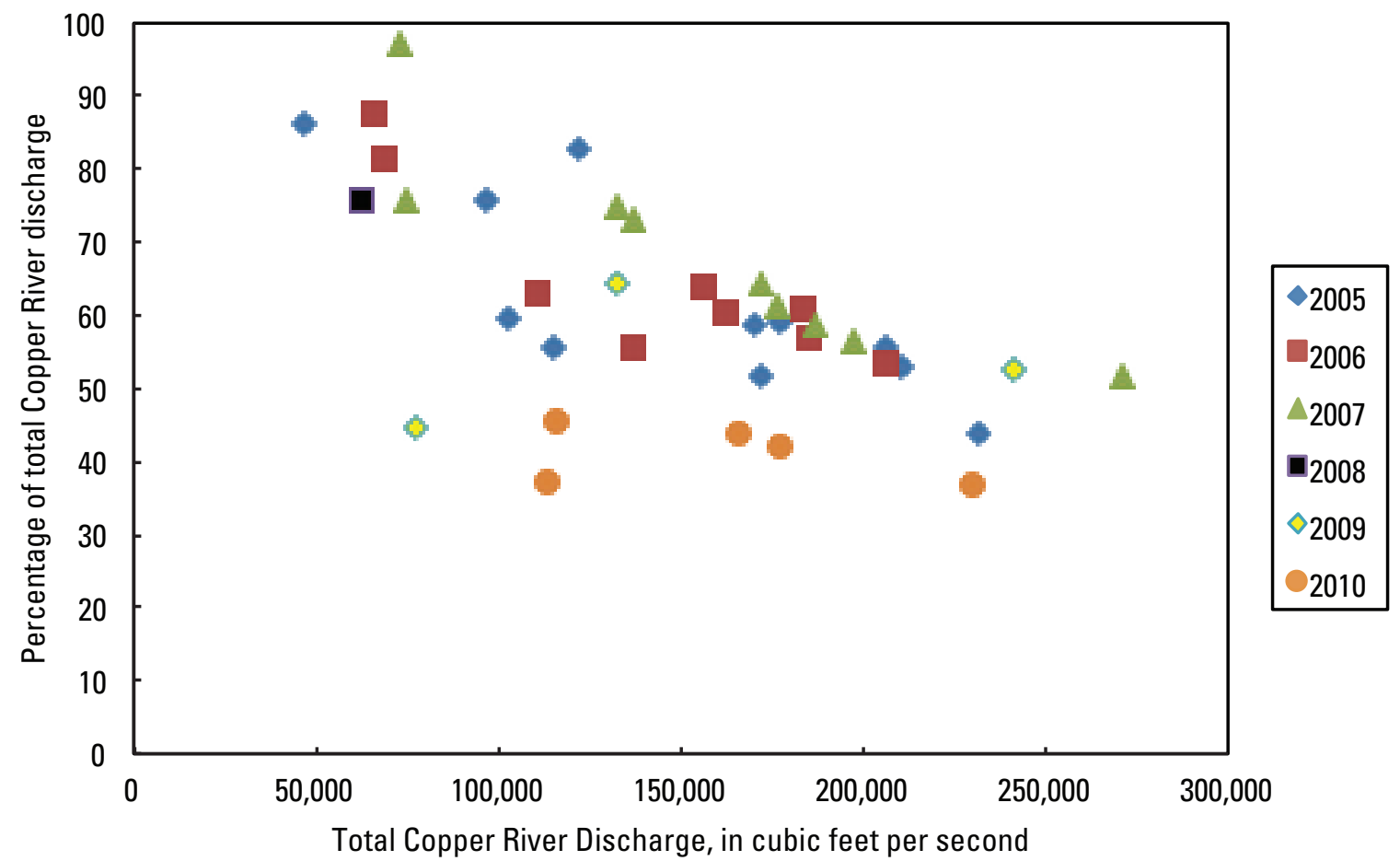

Figure 10. Discharge measurements from 2005-2010 at Copper River, Alaska, bridge number (BN) 342 and their percentage of the total river discharge. 


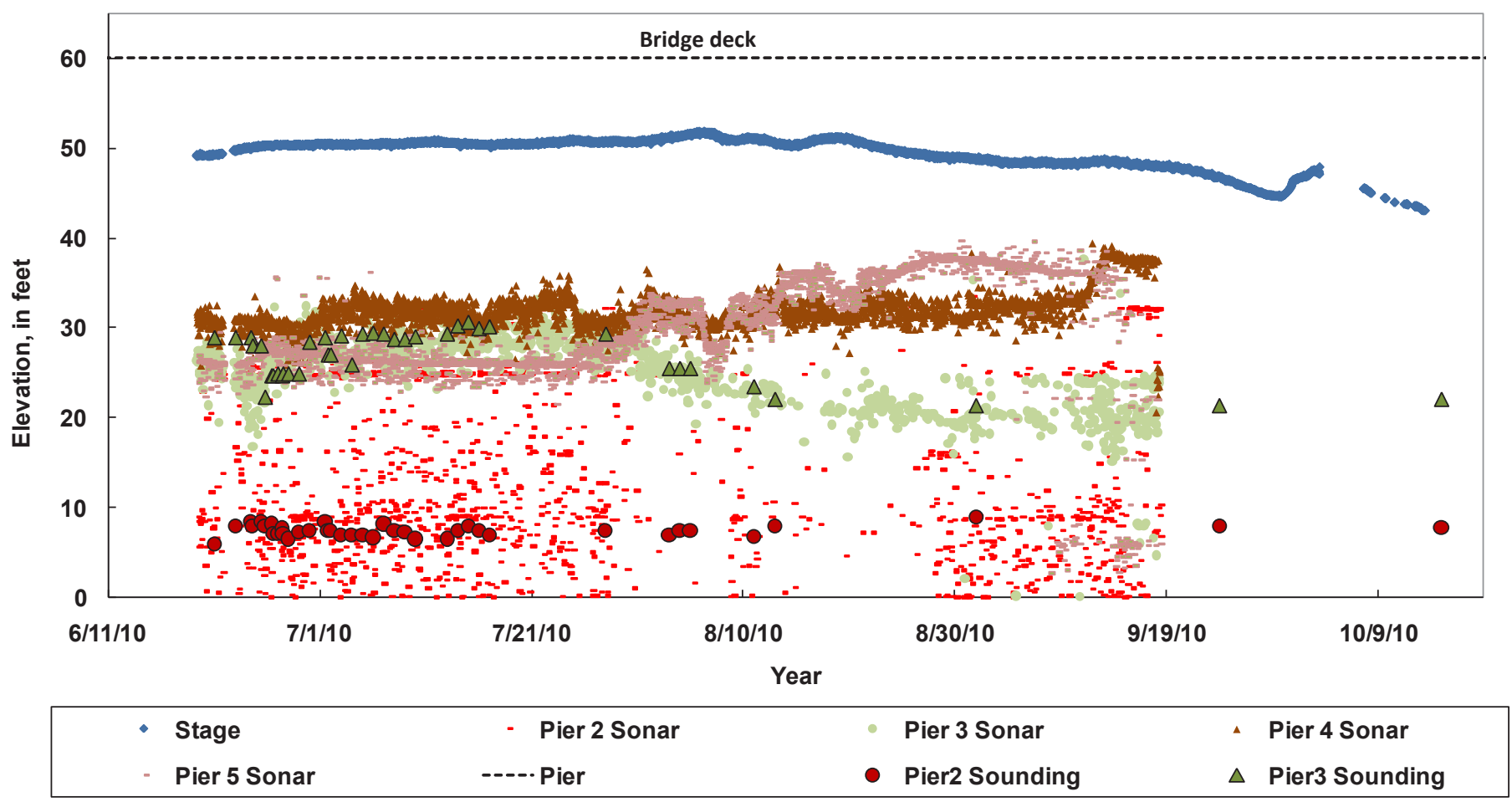

Figure 11. Pier soundings, stage, and sonar values from 2010 at Copper River, Alaska, bridge number (BN) 339. Air entrainment and a hydraulic jump at pier 2 limited the ability of the sonar to collect accurate data.

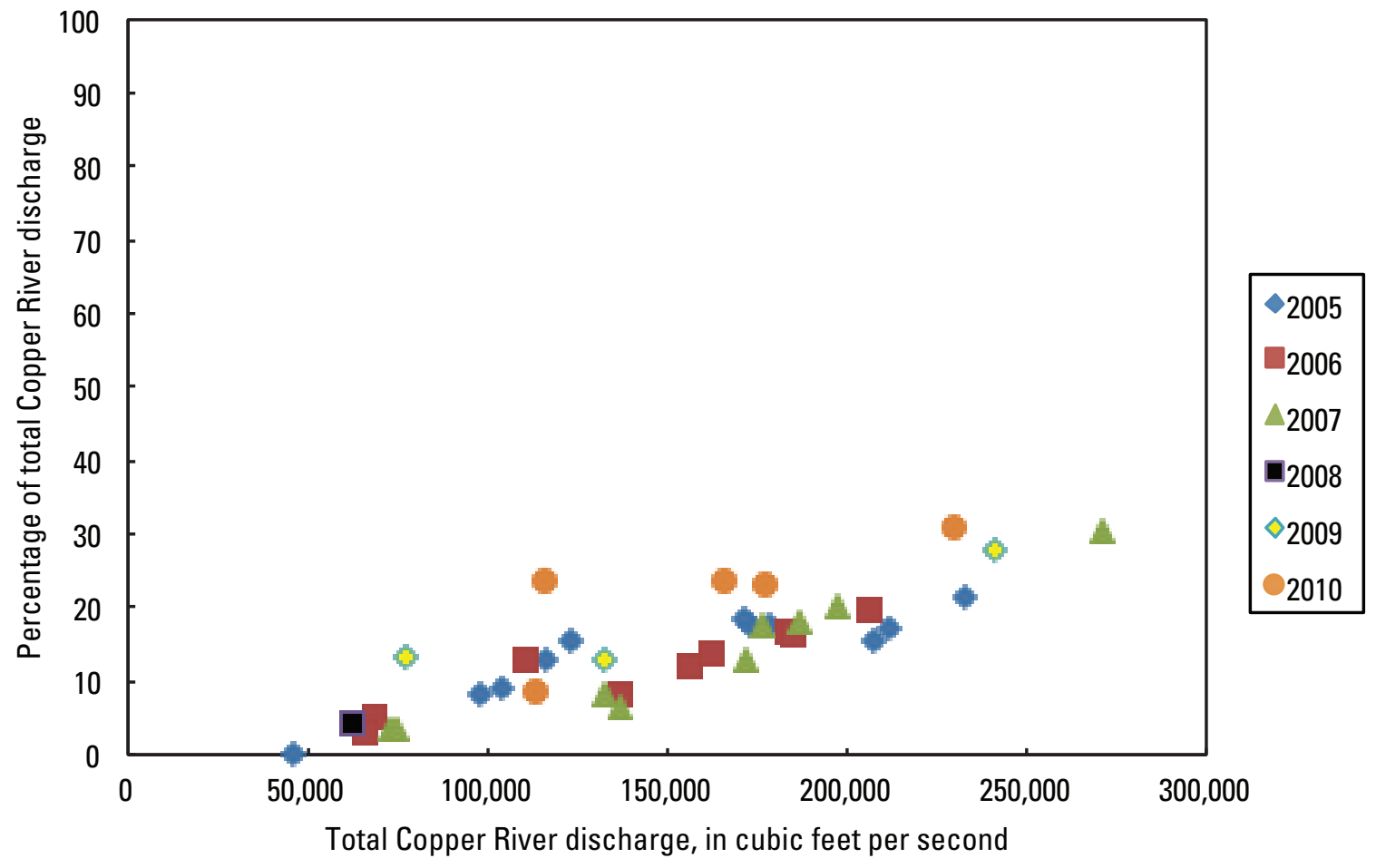

Figure 12. Discharge measurements from 2005-10 at Copper River, Alaska, bridge numbers (BN) 331, 1187, and 332, and their percentage of the total river discharge. Discharge represents the combined flow of BN 331, 1187, and 332. 


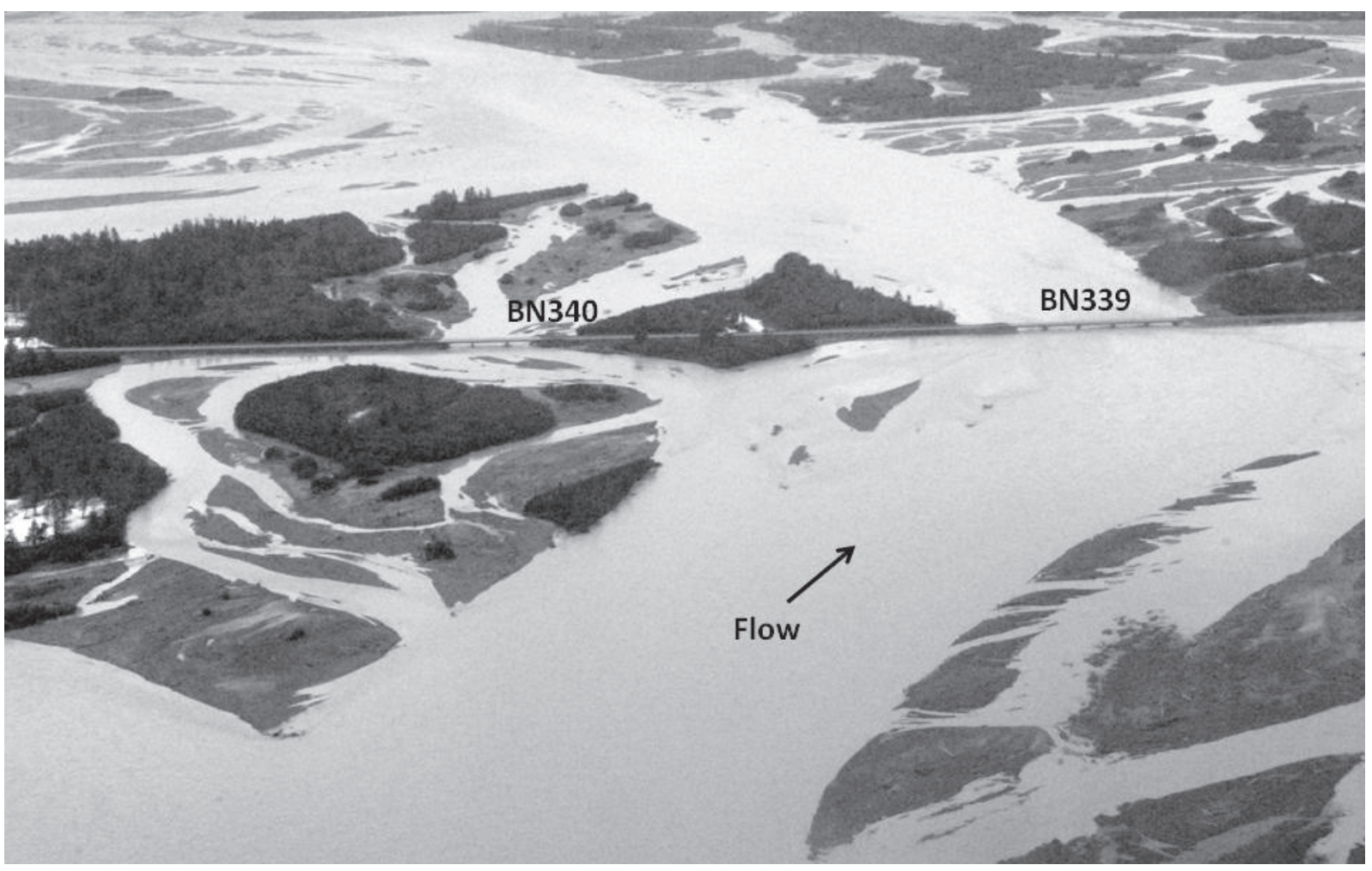

Figure 13. Aerial photograph of approach channels to Copper River, Alaska, bridge numbers (BN) 339 and 340 . Photograph was taken on July 1, 2010, at a discharge of $60,300 \mathrm{ft}^{3} / \mathrm{s}$ at BN 339 and a total river discharge of $160,000 \mathrm{ft}^{3} / \mathrm{s}$. (USGS photograph by J.S. Conaway.) 

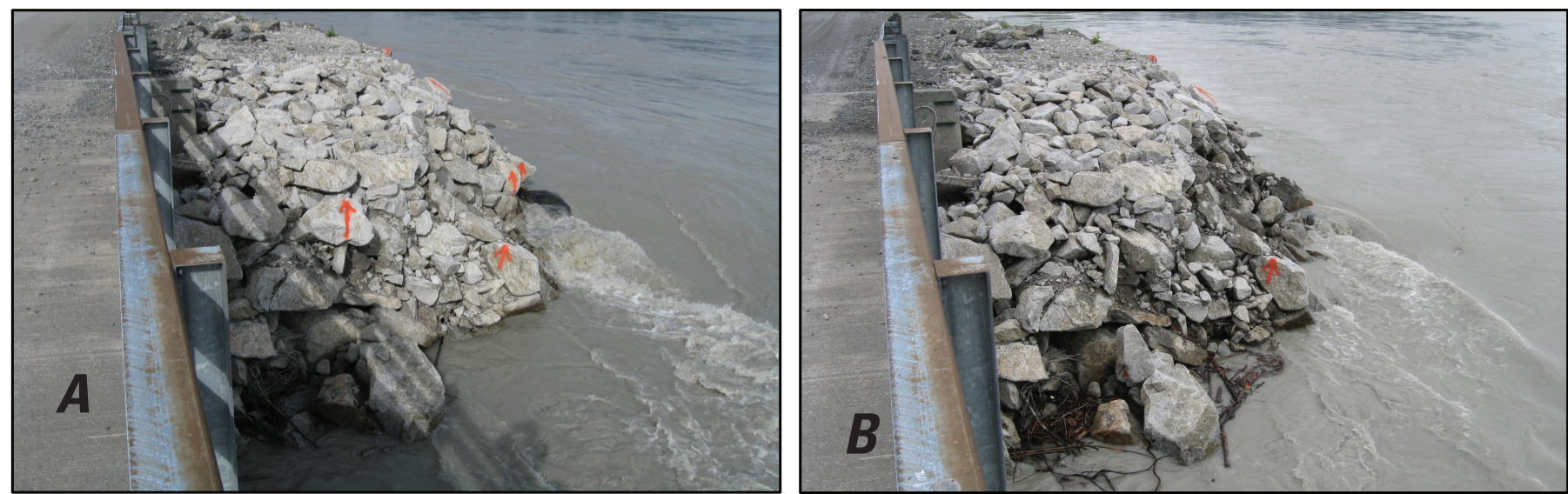

Figure 14. Photographs showing undermining and erosion of rip rap over a 24-hour period at the right bank abutment of Copper River, Alaska, bridge number (BN) 339 from $(A)$ June 24, 2010, to (B) June 25, 2010. Discharge at BN 339 was $60,600 \mathrm{ft}^{3} / \mathrm{s}$. Orange arrows were painted on rip rap to document movement or removal. (USGS photographs by P.V. Schauer.)

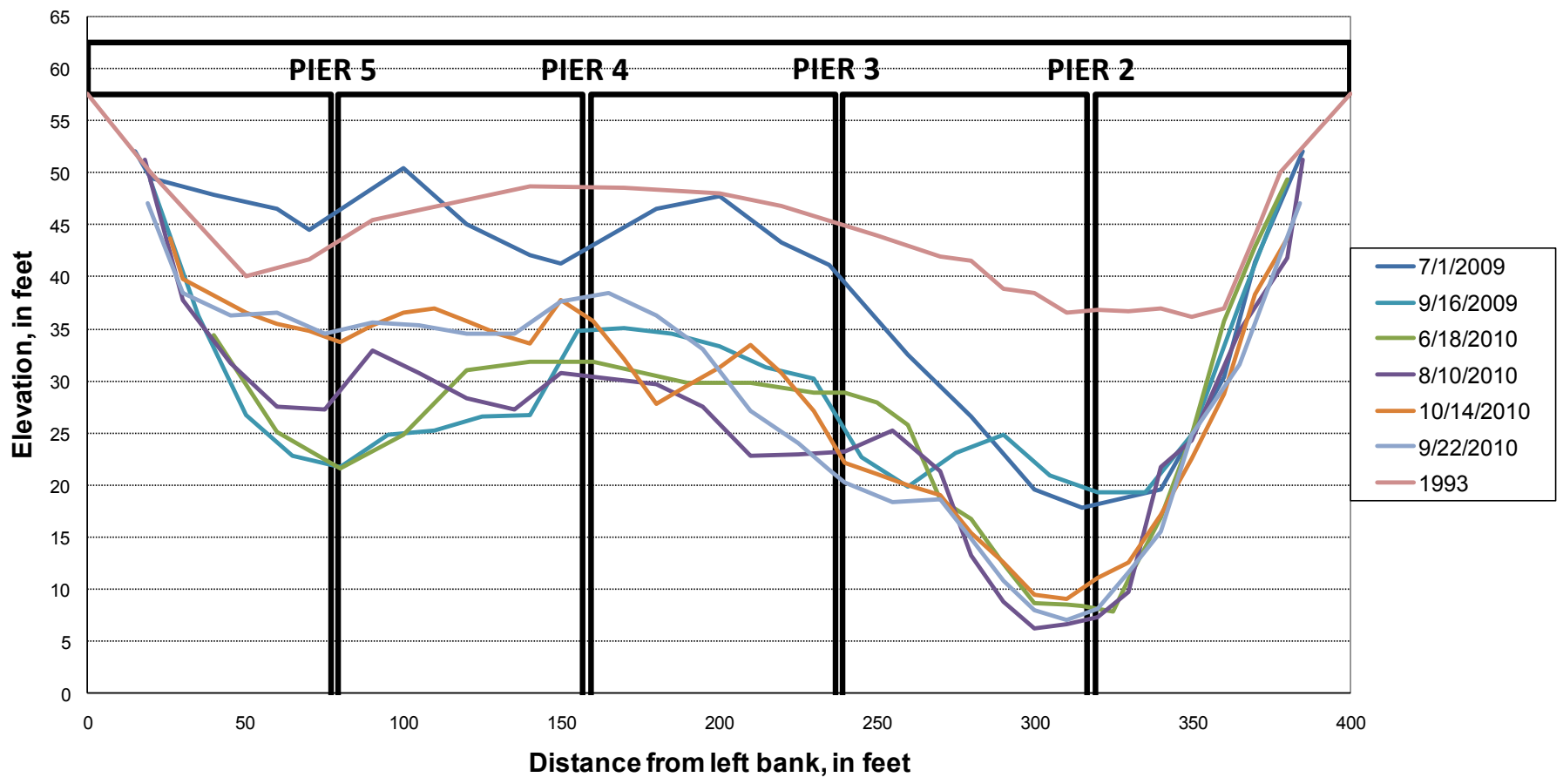

Figure 15. Surveyed cross sections along the downstream side of Copper River, Alaska, bridge number (BN) 339. 

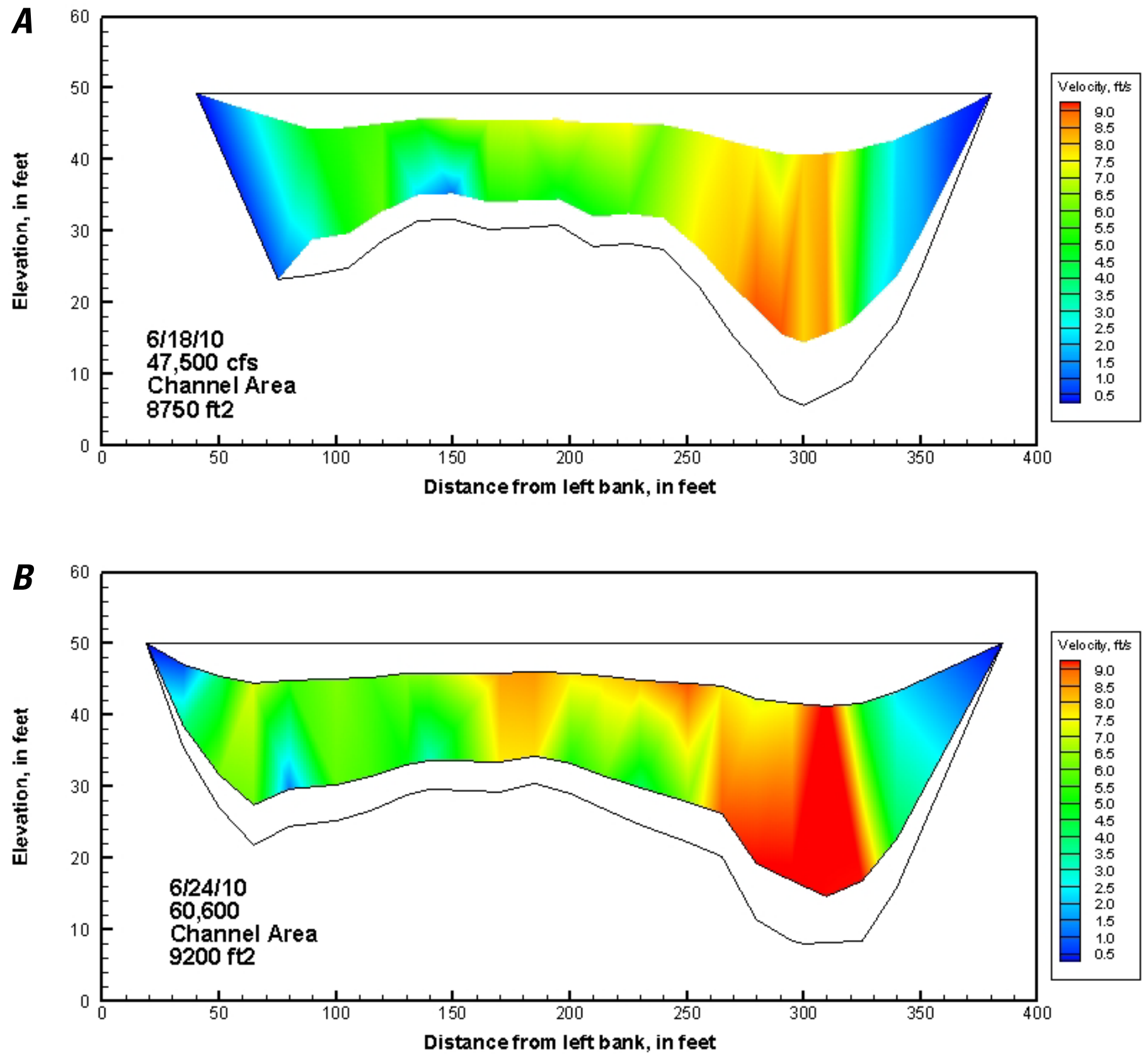

Figure 16. Velocity contour plots from discharge measurements made during 2010 at Copper River, Alaska, bridge number (BN) 339. $A$, June 18, 2010; $B$, June 24, 2010, C, June 30, 2010; D, July 7, 2010; E, July 12, 2010; F, July 27, 2010; G, August 10, 2010; $H$, August 31, 2010; I, September 22, 2010. 

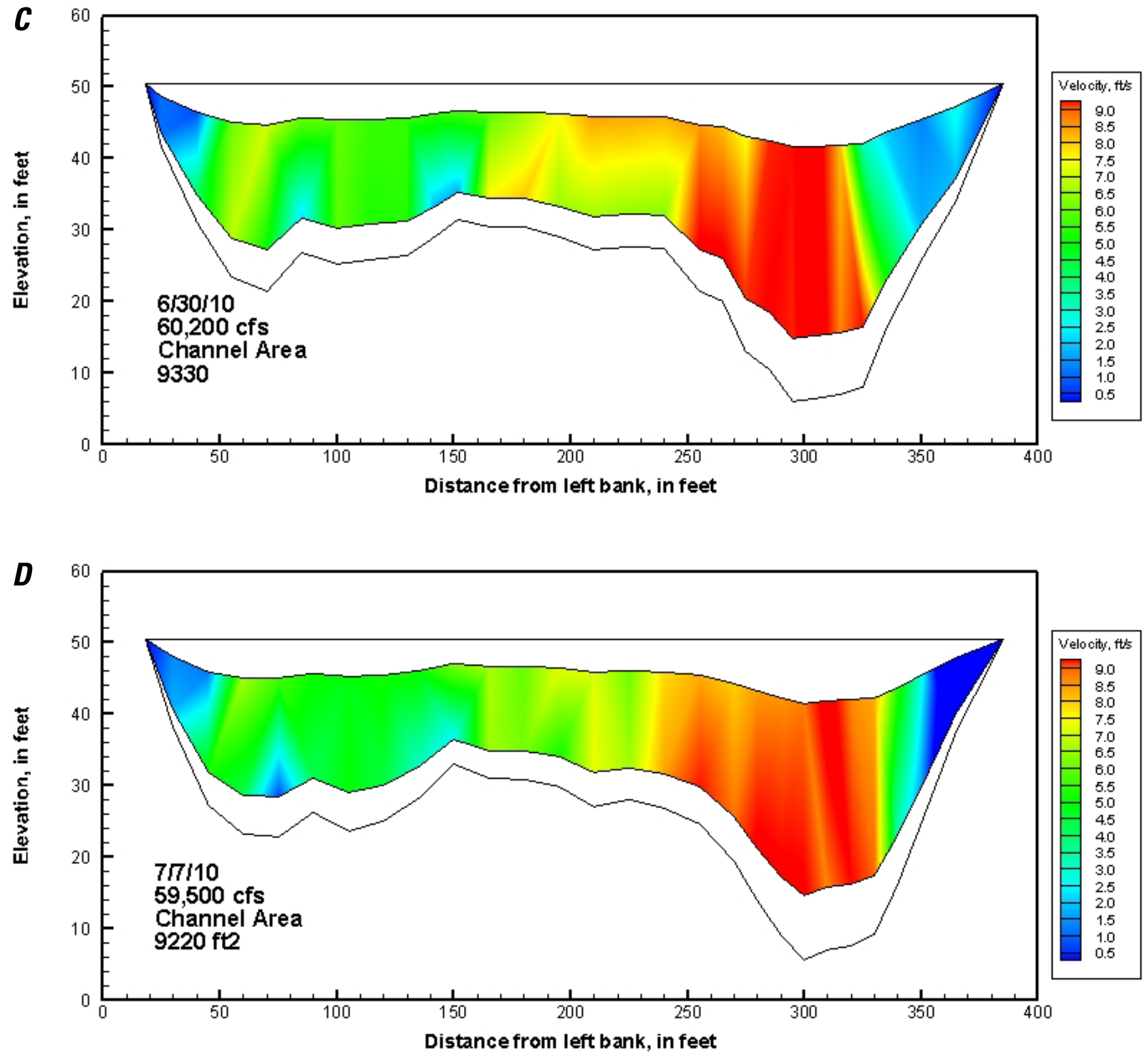

Figure 16.-Continued. 

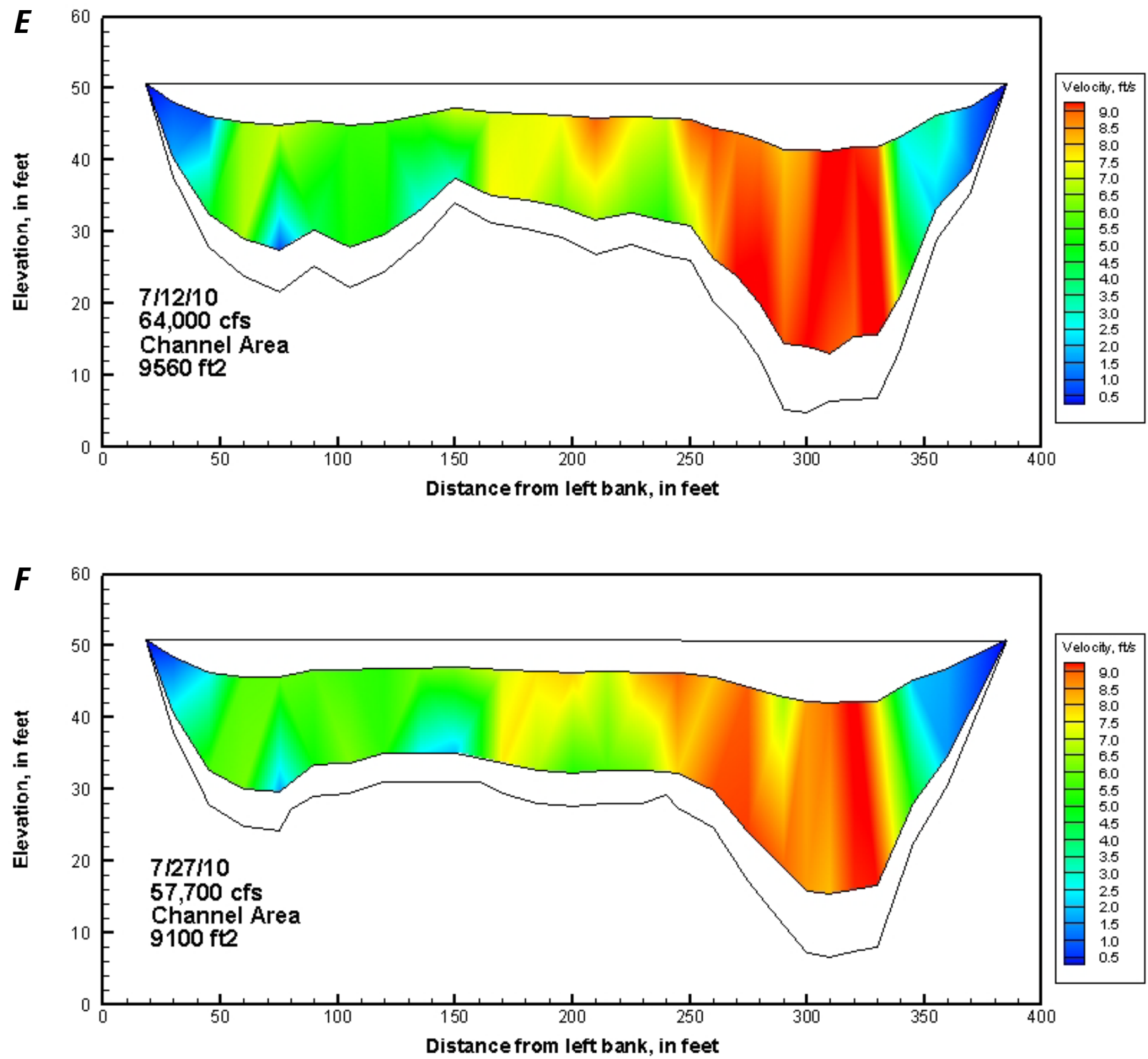

Figure 16.-Continued. 

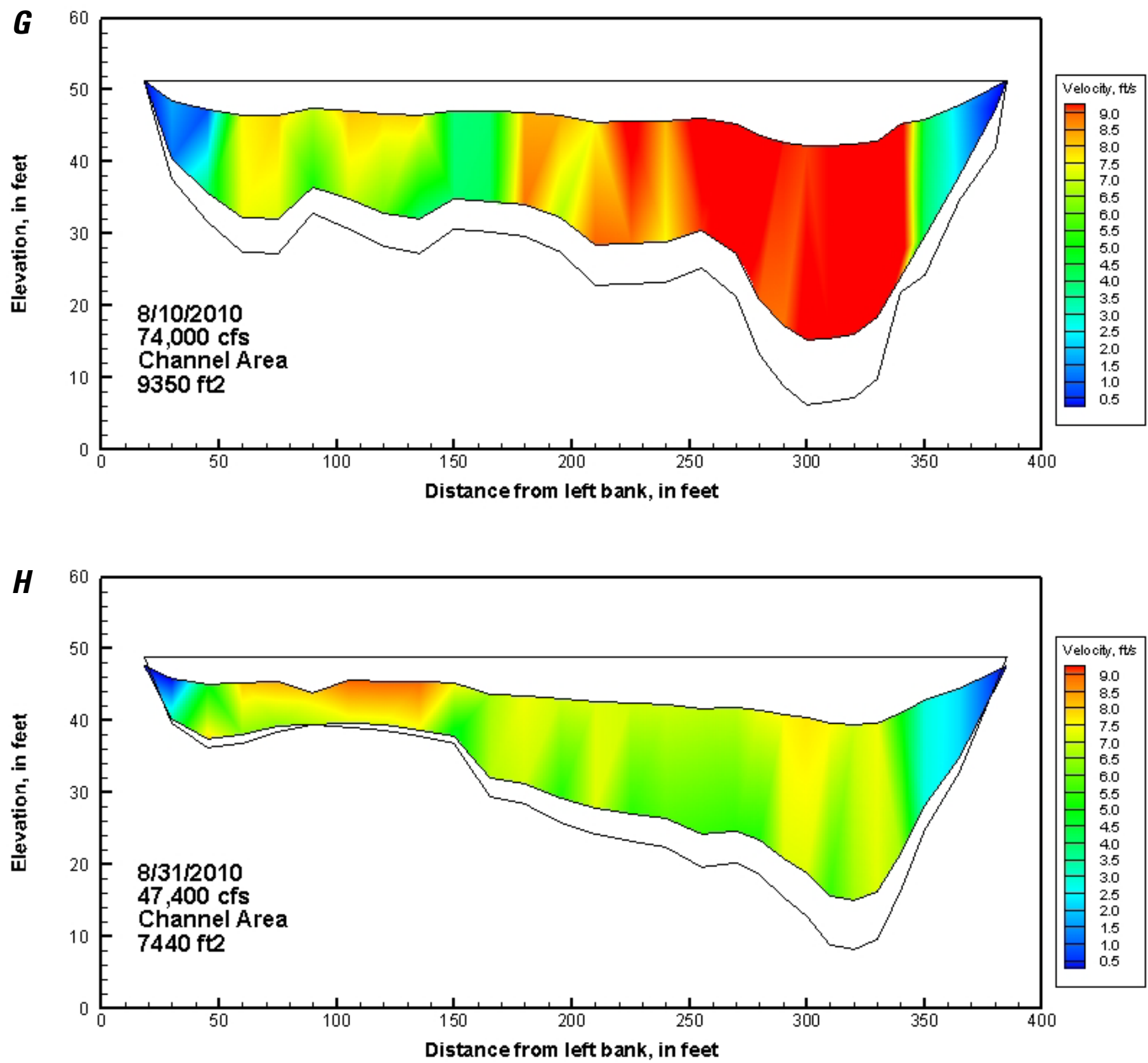

Figure 16.-Continued. 
22 Streamflow and Streambed Scour in 2010 at Bridge 339, Copper River, Alaska

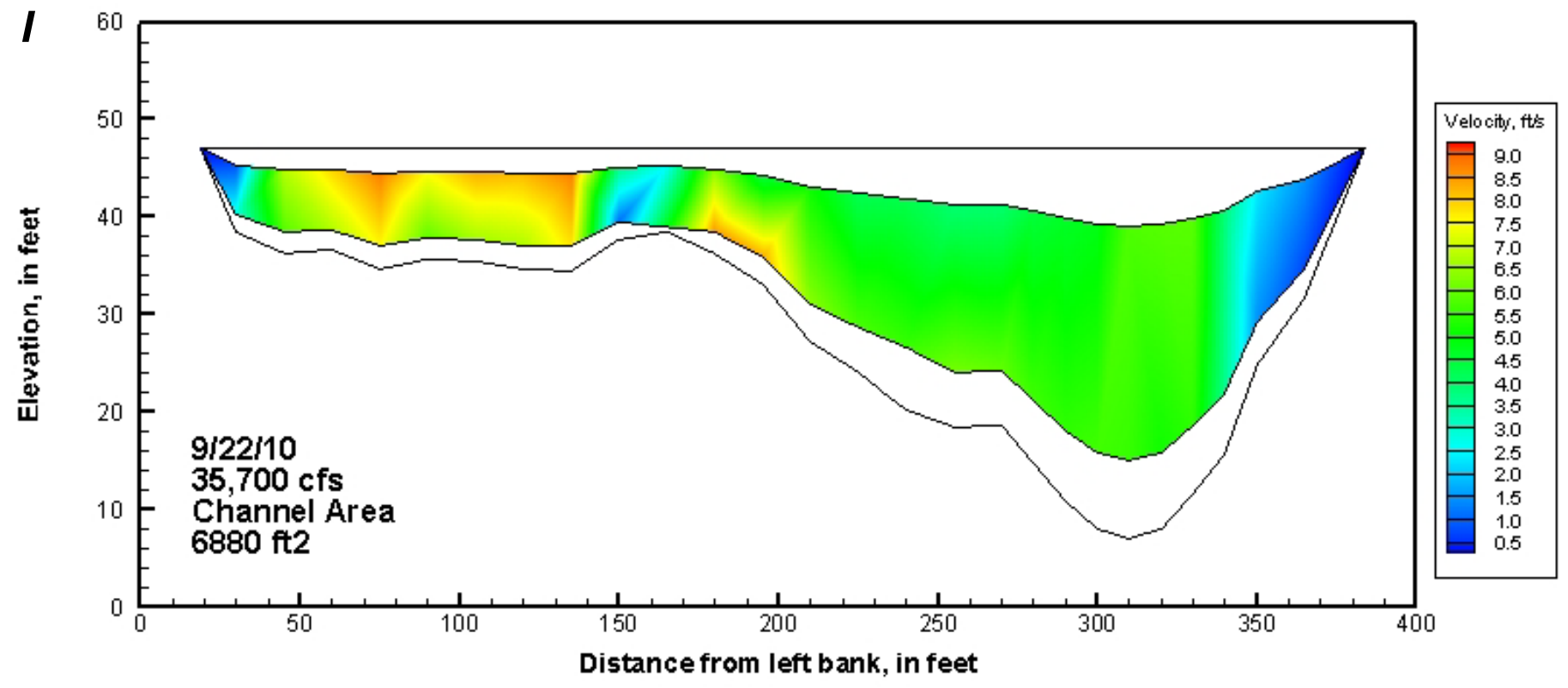

Figure 16.-Continued. 


\section{Tables 1 through 3}


Table 1. Discharge measurements made in 2010 at Copper River, Alaska, bridge numbers (BN) 339 and 342.

\begin{tabular}{rccccc}
\hline Date & $\begin{array}{c}\text { Discharge } \\
\text { at } \\
\text { BN339 } \\
\left(\mathbf{f t}^{3} / \mathbf{s}\right)\end{array}$ & $\begin{array}{c}\text { Percentage } \\
\text { of total } \\
\text { Copper River } \\
\text { discharge }\end{array}$ & $\begin{array}{c}\text { Discharge } \\
\text { at } \\
\text { BN342 } \\
\left(\mathbf{f t}^{3} / \mathbf{s}\right)\end{array}$ & $\begin{array}{c}\text { Percentage } \\
\text { of total } \\
\text { Copper } \\
\text { River } \\
\mathbf{d i s c h a r g e ~}^{\text {dischal }}\end{array}$ & $\begin{array}{c}\text { Total } \\
\text { Copper } \\
\text { River } \\
\mathbf{d i s c h a r g e ~}_{\left(\mathbf{f t}^{3} / \mathbf{s}\right)}\end{array}$ \\
\hline $6 / 9-10 / 2010$ & 45,300 & 39 & 53,000 & 46 & 118,000 \\
$6 / 30 / 2010$ & 60,300 & 38 & 72,500 & 44 & 160,000 \\
$7 / 7 / 2010$ & 59,500 & 37 & 74,350 & 42 & 159,000 \\
$8 / 10 / 2010$ & 74,000 & 34 & 85,000 & 37 & 219,000 \\
$8 / 31-9 / 1 / 2010$ & 47,400 & 42 & 42,200 & 37 & 114,000 \\
\hline
\end{tabular}

Table 2. Summary of discharge measurements made in 2010 at Copper River, Alaska, bridge number (BN) 339. [Channel area is computed from an elevation of $50.0 \mathrm{ft}$ ]

\begin{tabular}{|c|c|c|c|c|c|c|c|c|}
\hline Date & $\begin{array}{c}\text { Discharge } \\
\text { at } \\
\text { BN339 } \\
\left(\mathrm{ft}^{3} / \mathrm{s}\right)\end{array}$ & $\begin{array}{c}\text { Stage } \\
(\mathrm{ft})\end{array}$ & $\begin{array}{c}\text { Percentage } \\
\text { of total } \\
\text { Copper River } \\
\text { discharge }\end{array}$ & $\begin{array}{c}\text { Total } \\
\text { Copper } \\
\text { River } \\
\text { discharge } \\
\left(\mathrm{ft}^{3} / \mathrm{s}\right)\end{array}$ & $\begin{array}{c}\text { Channel } \\
\text { area } \\
\left(\mathrm{ft}^{2}\right)\end{array}$ & $\begin{array}{l}\text { Average } \\
\text { depth } \\
\text { (ft) }\end{array}$ & $\begin{array}{l}\text { Average } \\
\text { velocity } \\
\text { (ft } / \mathrm{s})\end{array}$ & $\begin{array}{c}\text { Minimum } \\
\text { bed } \\
\text { elevation } \\
\text { (ft) }\end{array}$ \\
\hline $6 / 9 / 2010$ & 45,300 & 49.6 & 39 & 114,000 & 8,860 & 23.8 & 5.50 & 4.9 \\
\hline $6 / 18 / 2010$ & 46,700 & 49.3 & 42 & 105,000 & 8,900 & 23.8 & 5.20 & 5.7 \\
\hline $6 / 24 / 2010$ & 60,600 & 50.0 & 44 & 137,000 & 9,160 & 25.1 & 6.60 & 8.0 \\
\hline $6 / 30 / 2010$ & 60,300 & 50.5 & 38 & 160,000 & 9,150 & 25.4 & 6.53 & 6.0 \\
\hline $7 / 7 / 2010$ & 59,500 & 50.6 & 37 & 159,000 & 9,020 & 25.1 & 6.45 & 5.6 \\
\hline $7 / 12 / 10$ & 64,000 & 50.6 & 36 & 180,000 & 9,340 & 26.1 & 6.61 & 4.9 \\
\hline $7 / 27 / 2010$ & 57,700 & 51.0 & 32 & 178,000 & 8,850 & 24.8 & 6.35 & 6.7 \\
\hline $8 / 10 / 2010$ & 74,000 & 51.3 & 34 & 219,000 & 8,890 & 25.5 & 7.90 & 6.3 \\
\hline $8 / 31 / 2010$ & 47,400 & 48.9 & 42 & 113,000 & 7,830 & 20.3 & 6.38 & 8.2 \\
\hline $9 / 22 / 2010$ & 35,700 & 47.1 & 49 & 72,500 & 7,920 & 18.7 & 5.18 & 7.1 \\
\hline
\end{tabular}

Table 3. Pile-tip elevations, minimum embedment depths (35 foot minimum), and minimum measured bed elevations at Copper River, Alaska, bridge number (BN) 339 .

\begin{tabular}{lcccc}
\hline \multicolumn{1}{|c}{ Pier number } & $\begin{array}{c}\text { Pile-tip } \\
\text { elevation } \\
\text { (ft) }\end{array}$ & $\begin{array}{c}\text { Minimum } \\
\text { embedment } \\
\text { elevation } \\
\text { (ft) }\end{array}$ & $\begin{array}{c}\text { Minimum } \\
\text { elevation } \\
\text { (ft) }\end{array}$ & Date \\
\hline $\begin{array}{l}\text { Pier 2 upstream } \\
\text { Pier 2 }\end{array}$ & -39.3 & -4.3 & 5.6 & $7 / 27 / 2010$ \\
downstream & -29.8 & 5.2 & 5.9 & $6 / 21 / 2010$ \\
Pier 3 upstream & -13.8 & 21.2 & 23.5 & $10 / 14 / 2010$ \\
$\begin{array}{l}\text { Pier 3 } \\
\text { downstream }\end{array}$ & -23.1 & 11.9 & 21.4 & $9 / 24 / 2010$ \\
$\begin{array}{l}\text { Pier 4 upstream } \\
\text { Pier 4 }\end{array}$ & -19.0 & 16.0 & 29.1 & $10 / 14 / 2010$ \\
downstream & -25.5 & 9.5 & 27.7 & $6 / 28 / 2010$ \\
$\begin{array}{l}\text { Pier 5 upstream } \\
\text { Pier 5 }\end{array}$ & -16.0 & 19.0 & 21.6 & $6 / 28 / 2010$ \\
downstream & -14.7 & 20.3 & 21.7 & $7 / 12 / 2010$ \\
\hline
\end{tabular}


Produced in the Menlo Park Publishing Service Center, California Manuscript approved for publication, August 26, 2011

Text edited by James W. Hendley II

Layout and design by Stephen L. Scott 


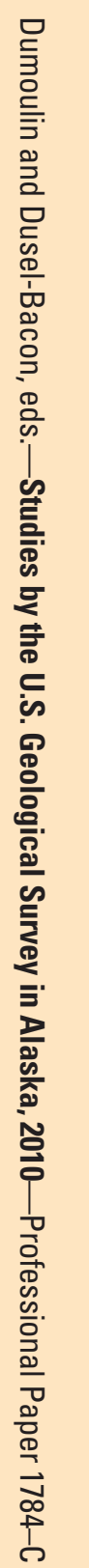

